\title{
Status and Prospects of Cubic Silicon Carbide Power Electronics Device Technology
}

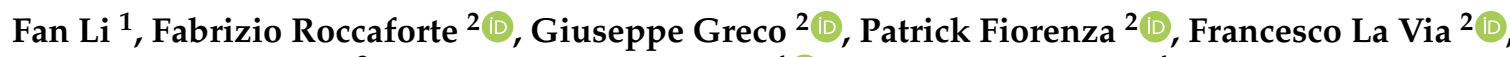 \\ Amador Pérez-Tomas ${ }^{3}$, Jonathan Edward Evans $\left.{ }^{4} \mathbb{(}\right)$, Craig Arthur Fisher ${ }^{4}$, Finn Alec Monaghan ${ }^{4}$, \\ Philip Andrew Mawby ${ }^{5}$ and Mike Jennings $4, *$ (i)
}

1 Newport Wafer Fab, Cardiff Rd, Duffryn, Newport NP10 8YJ, UK; Fan.Li@nptwf.com

2 Consiglio Nazionale delle Ricerche-Istituto per la Microelettronica e Microsistemi (CNR-IMM), Strada VIII n. 5-Zona Industriale, 95121 Catania, Italy; fabrizio.roccaforte@imm.cnr.it (F.R.); giuseppe.greco@imm.cnr.it (G.G.); patrick.fiorenza@imm.cnr.it (P.F.); francesco.lavia@imm.cnr.it (F.L.V.)

3 Institut Català de Nanociència i Nanotecnologia (ICN2), Universitat Autònoma de Barcelona, 08193 Barcelona, Spain; amador.perez@icn2.cat

4 Faculty of Science, Bay Campus, College of Engineering, Swansea University, Fabian Way, Crymlyn Burrows, Skewen, Swansea SA1 8EN, UK; j.e.evans@swansea.ac.uk (J.E.E.); c.a.fisher@swansea.ac.uk (C.A.F.); f.a.j.monaghan.909302@swansea.ac.uk (F.A.M.)

5 School of Engineering, The University of Warwick, Gibbet Hill Rd, Coventry CV4 7AL, UK; p.a.mawby@swansea.ac.uk

Citation: Li, F.; Roccaforte, F.; Greco, G.; Fiorenza, P.; La Via, F.; Pérez-Tomas, A.; Evans, J.E.; Fisher, C.A.; Monaghan, F.A.; Mawby, P.A.; et al. Status and Prospects of Cubic Silicon Carbide Power Electronics Device Technology. Materials 2021, 14, 5831. https://doi.org/10.3390/ ma14195831

Academic Editor: Alexander A Lebedev

Received: 20 July 2021

Accepted: 25 September 2021

Published: 5 October 2021

Publisher's Note: MDPI stays neutral with regard to jurisdictional claims in published maps and institutional affiliations.

Copyright: (c) 2021 by the authors. Licensee MDPI, Basel, Switzerland. This article is an open access article distributed under the terms and conditions of the Creative Commons Attribution (CC BY) license (https:// creativecommons.org/licenses/by/ $4.0 /)$.
* Correspondence: m.r.jennings@swansea.ac.uk

Abstract: Wide bandgap (WBG) semiconductors are becoming more widely accepted for use in power electronics due to their superior electrical energy efficiencies and improved power densities. Although WBG cubic silicon carbide (3C-SiC) displays a modest bandgap compared to its commercial counterparts (4H-silicon carbide and gallium nitride), this material has excellent attributes as the WBG semiconductor of choice for low-resistance, reliable diode and MOS devices. At present the material remains firmly in the research domain due to numerous technological impediments that hamper its widespread adoption. The most obvious obstacle is defect-free 3C-SiC; presently, 3C$\mathrm{SiC}$ bulk and heteroepitaxial (on-silicon) display high defect densities such as stacking faults and antiphase boundaries. Moreover, heteroepitaxy 3C-SiC-on-silicon means low temperature processing budgets are imposed upon the system (max. temperature limited to $\sim 1400{ }^{\circ} \mathrm{C}$ ) limiting selective doping realisation. This paper will give a brief overview of some of the scientific aspects associated with 3C-SiC processing technology in addition to focussing on the latest state of the art results. A particular focus will be placed upon key process steps such as Schottky and ohmic contacts, ion implantation and MOS processing including reliability. Finally, the paper will discuss some device prototypes (diodes and MOSFET) and draw conclusions around the prospects for 3C-SiC devices based upon the processing technology presented.

Keywords: 3C-SiC; cubic silicon carbide; power electronics

\section{Introduction}

Power electronics is a key enabling technology for energy generation, transmission, distribution and motion. The importance of this technology is emphasised by the fact that a $40 \%$ increase in energy consumption within 20 years is expected [1]. Moreover, $80 \%$ of electrical energy will be processed by a power electronic converter by 2030 [2] Recently, power electronic converter and device technology has been driven by the huge demand seen within the electric vehicle (EV) sector. EV sales are set to reach 18 million by 2023 , representing $16.2 \%$ of total global vehicle sales [3]. Together, these circumstances project the ever-increasing demand for power electronics on a global scale. In order to meet this required capacity and while still safeguarding our environment, power converters with near- $100 \%$ energy-efficiency that are lightweight and compact need to be delivered. 
Furthermore, attention must be paid to the lifetime (or longevity) of these systems, meaning increased reliability within the field.

Such a step-change intervention within the world of power electronics requires advancements within the fundamental semiconductor materials that serve to underpin our energy landscape. The underpinning technologies with respect to power electronics are its constituent high-voltage semiconductor devices. Consequently, these devices represent the largest cost associated with the overall power converter $(40 \%$ of the total bill of materials for a typical $50 \mathrm{~kW}$ EV inverter). Traditionally for the last 50 years, silicon (Si) has dominated the power electronics industry as the semiconductor material of choice. However, the demand for increased energy-efficiency and power density together with higher voltage and current operation mean that a new era in semiconductor materials has dawned. Wide bandgap (WBG) semiconductor materials come with the promise to overcome the inherent material limits imposed by $\mathrm{Si}$. $4 \mathrm{H}$-silicon carbide $(4 \mathrm{H}-\mathrm{SiC})$ and gallium nitride ( $2 \mathrm{H}-\mathrm{GaN}$ or $\mathrm{GaN}$ ) have emerged as the WBG materials of choice that have replaced Si in many power electronic applications.

For the moment, GaN devices that are based mainly on the high electron mobility transistor (HEMT) architecture are limited commercially to a maximum of $650 \mathrm{~V}$. From the reliability perspective, GaN HEMTs have traditionally suffered from a poor thermal conductivity and the "current collapse" phenomenon, degrading their ability to function within harsh environments and high reliability electronics [4]. 4H-SiC, on the other hand, suffers from numerous reliability issues that are hampering its widespread uptake within the automotive sector. In particular, although SiC Trench MOSFETs exhibit superior onstate resistance compared to both $\mathrm{GaN}$ and silicon, the ruggedness of the gate oxide is the limiting factor. Gonzalez et al. [5] note that the competing WBG material technologies centre around the $650 \mathrm{~V}$ mark.

Early stage research devices are based on so-called ultrawide bandgap oxide materials such as gallium oxide $\left(\mathrm{Ga}_{2} \mathrm{O}_{3}\right.$, with $\beta-\mathrm{Ga}_{2} \mathrm{O}_{3}$ being the most stable). Thus far, $\beta-\mathrm{Ga}_{2} \mathrm{O}_{3}$ suffers from a poor thermal conductivity, a modest bulk mobility and lack of p-type conductivity. Other ultrawide bandgap materials, including diamond and aluminium nitride (AlN), suffer from a lack of n-type conductivity and a poor bulk electron mobility, respectively. It should be noted that $\mathrm{GaN}, \beta-\mathrm{Ga}_{2} \mathrm{O}_{3}$, and $\mathrm{AlN}$ are direct bandgap materials, which severely limits bipolar operation, which is required for higher voltages [6].

This review will place the cubic SiC (3C-SiC) material into the context of power electronic devices; however, it should be noted that other application areas such as biomedical sensors and micro-electromechanical systems (MEMS) are also appropriate and more popular for this $\mathrm{SiC}$ polytype. The authors will endeavour to provide a brief insight into some of the advantages of $3 \mathrm{C}-\mathrm{SiC}$ from the scientific materials perspective in addition to some of the technological issues that must be overcome to realise competitive power MOSFETs and diodes. In particular, the focus will be placed on fundamental semiconductor fabrication technologies; the $3 \mathrm{C}-\mathrm{SiC} / \mathrm{SiO}_{2}$ metal-oxide-semiconductor (MOS) interface, ion implantation, ohmic and Schottky contacts.

\section{Cubic Silicon Carbide (3C-SiC): Structure and Material Properties for Power Electronic Application}

The cubic form of $\mathrm{SiC}$, coined ' $3 \mathrm{C}-\mathrm{SiC}$ ', is one of many stable polytypes characterised by its wide bandgap and bilayer stacking sequence of ABCABC .. . [7]. The resulting structure is a pure zinc-blende exhibiting an energy band gap of 2.3-2.4 eV [8], lower compared to other major $\mathrm{SiC}$ polytypes, but with a higher electron mobility and saturation velocity owing to its higher degree of symmetry. Although 3C-SiC has a smaller energy bandgap compared to its wide bandgap counterparts such as $4 \mathrm{H}-\mathrm{SiC}$ and $\mathrm{GaN}$, this material displays isotropy for many of the desired power device material characteristics such as avalanche coefficients and high electron mobility $[9,10]$. Another advantage of 3C-SiC is its relatively large thermodynamic stability meaning that bulk material can be grown at reduced thermal budgets (below $1500{ }^{\circ} \mathrm{C}$ ). Table 1 shows the important physical and electrical properties of 3C-SiC compared to other commercial power device materials such 
as $\mathrm{Si}, \mathrm{GaN}$ and $4 \mathrm{H}-\mathrm{SiC}$. Likewise included are promising oxide and nitride ultra-WBG materials. The 3C-SiC intrinsic carrier concentration $\left(\sim 10^{-1} \mathrm{~cm}^{-3}\right)$ is several orders of magnitude lower than in $\mathrm{Si}$, but not as low as $4 \mathrm{H}-\mathrm{SiC}$ or $\mathrm{GaN}$. Moreover, 3C-SiC has a thermal conductivity three times that of $\mathrm{Si}$. Consequently, 3C-SiC devices should have lower leakage currents with the ability to operate at moderately higher temperatures when compared to $\mathrm{Si}$ and GaN. Other key aspects are the reasonable critical electric field value resulting in a higher breakdown of the material. On analysis of these material properties, $3 \mathrm{C}-\mathrm{SiC}$ is a promising semiconductor for power semiconductor devices in the region of 600-1000 V. On reflection, there exists the possibility to obtain a targeted breakdown voltage $\left(V_{B}\right)$ with thinner, more highly doped drift layers, which results in a significant reduction of the specific on-resistance $\left(\mathrm{R}_{\mathrm{ON}}\right)$ compared to $\mathrm{Si}$ devices. Therefore, devices that are smaller and more efficient can be fabricated, minimizing both the static and dynamic losses.

Table 1. Appropriate physical and electrical properties of cubic silicon carbide (3C-SiC) compared to other wide bandgap materials (data taken at $300 \mathrm{~K}$ ).

\begin{tabular}{|c|c|c|c|c|c|c|c|c|}
\hline Material & $\begin{array}{c}\text { Band Gap, } \\
(\mathrm{eV})\end{array}$ & $\begin{array}{l}\text { Intrinsic } \\
\text { Carrier } \\
\text { Conc., } \\
\left(\mathrm{cm}^{-3}\right)\end{array}$ & $\begin{array}{l}\text { Dielectric } \\
\text { Constant }\end{array}$ & $\begin{array}{l}\text { Electron } \\
\text { Mobility } \\
\left(\mathrm{cm}^{2} / \mathrm{Vs}\right)\end{array}$ & $\begin{array}{l}\text { Critical } \\
\text { Electric } \\
\text { Field } \\
(\mathrm{MV} / \mathrm{cm})\end{array}$ & $\begin{array}{l}\text { Saturation } \\
\text { Velocity } \\
\left(10^{7} \mathrm{~cm} / \mathrm{s}\right)\end{array}$ & $\begin{array}{l}\text { Thermal } \\
\text { Conductivity } \\
\text { (W/cmK) }\end{array}$ & $\begin{array}{c}\text { Baliga } \\
\text { Figure of } \\
\text { Merit }\end{array}$ \\
\hline $\mathrm{Si}$ & 1.12 & $1.5 \times 10^{10}$ & 11.8 & 1350 & 0.2 & 1.0 & 1.5 & 1 \\
\hline GaAs & 1.42 & $1.8 \times 10^{6}$ & 13.1 & 8500 & 0.4 & 1.2 & 0.55 & 29 \\
\hline 3C-SiC & 2.36 & $1.5 \times 10^{-1}$ & 9.7 & 800 & 1.4 & 2.5 & 3.2 & 86 \\
\hline $4 \mathrm{H}-\mathrm{SiC}$ & 3.26 & $8.2 \times 10^{-9}$ & 10 & $\begin{array}{l}720^{a} \\
650^{c}\end{array}$ & 2.8 & 2.0 & 4.5 & 556 \\
\hline $2 \mathrm{H}-\mathrm{GaN}$ & 3.39 & $1.9 \times 10^{-10}$ & 9.9 & $\begin{array}{l}1000^{a} \\
2000^{* *}\end{array}$ & $\begin{array}{c}3.75^{\mathrm{a}} \\
3.3^{*}\end{array}$ & 2.5 & 1.3 & 3175 \\
\hline $\mathrm{Ga}_{2} \mathrm{O}_{3}$ & 4.85 & $\begin{array}{c}2.6 \times 10^{-9} \\
-1.0 \times \\
10^{-22}\end{array}$ & 10 & 300 & 8 & $1.8-2.0$ & $0.1-0.3$ & 6171 \\
\hline Diamond & 5.45 & $1.6 \times 10^{-27}$ & 5.5 & 3800 & 10 & 2.7 & 22 & $8.4 \times 10^{4}$ \\
\hline $2 \mathrm{H}-\mathrm{AlN}$ & 6.2 & $10^{-34}$ & 8.5 & 300 & $12 *$ & 1.7 & 2.85 & $1.8 \times 10^{4}$ \\
\hline
\end{tabular}

The 3C-SiC Baliga figure of merit (BFOM) and BFOM for high-frequency, high-power unipolar switches (BHFFOM) [11] are 140 and 25, respectively. These values seem very modest compared to the equivalent values for more advanced WBG power semiconductors such as $4 \mathrm{H}-\mathrm{SiC}$ and $\mathrm{GaN}$. These key performance indicators for power semiconductors quantify the minimum conduction loss during DC operation (BFOM) and the minimum conduction loss at high frequencies (BHFFOM). Indeed, examination of these values suggests that lower resistance devices are possible based on $4 \mathrm{H}-\mathrm{SiC}$ and $\mathrm{GaN}$ when compared to 3C-SiC. However, this advantage must be weighed against power device reliability and field lifetime within a converter application. In this regard, $3 \mathrm{C}-\mathrm{SiC}$ is the clear winner, benefitting from a favourable metal-oxide-semiconductor (MOS) interface when compared to its $4 \mathrm{H}-\mathrm{SiC}$ counterpart. The bandgap value $\left(\mathrm{E}_{\mathrm{g}}\right)$ for $3 \mathrm{C}-\mathrm{SiC}$ was reported by Bimberg et al. [12] and later by Goldberg et al. [8] (see Table 1). Figure 1 shows the conduction band offsets of the major power semiconductors with silicon dioxide $\left(\mathrm{SiO}_{2}\right)$. From the figure it is seen that the band offset $\left(\Phi_{\mathrm{B}}\right)$ between $3 \mathrm{C}-\mathrm{SiC}$ and $\mathrm{SiO}_{2}$ is $3.7 \mathrm{eV}$. This is significantly larger when compared to the other power semiconductors with their values ranging between $2.7 \mathrm{eV}-3.2 \mathrm{eV}$.

The ramifications of this important property are realised in terms of reduced gate leakage current for a given oxide electric field. The important current transport mecha- 
nism which relates to this physical parameter is the Fowler-Nordheim (F-N) tunnelling mechanism. The F-N tunnelling current is given by:

$$
J_{F N}=\frac{A}{\Phi_{B}} E_{o x}{ }^{2} \exp \left(-\frac{B \Phi_{B}^{3 / 2}}{E_{o x}}\right)
$$

where $E_{o x}$ is the oxide electric field, $\Phi_{B}$ is the barrier height and $\mathrm{A}, \mathrm{B}$ are constant values. It can be seen that due to F-N tunnelling the oxide electric field value must be reduced by 2-3 times in $4 \mathrm{H}-\mathrm{SiC}$ compared to the 3C-SiC system.

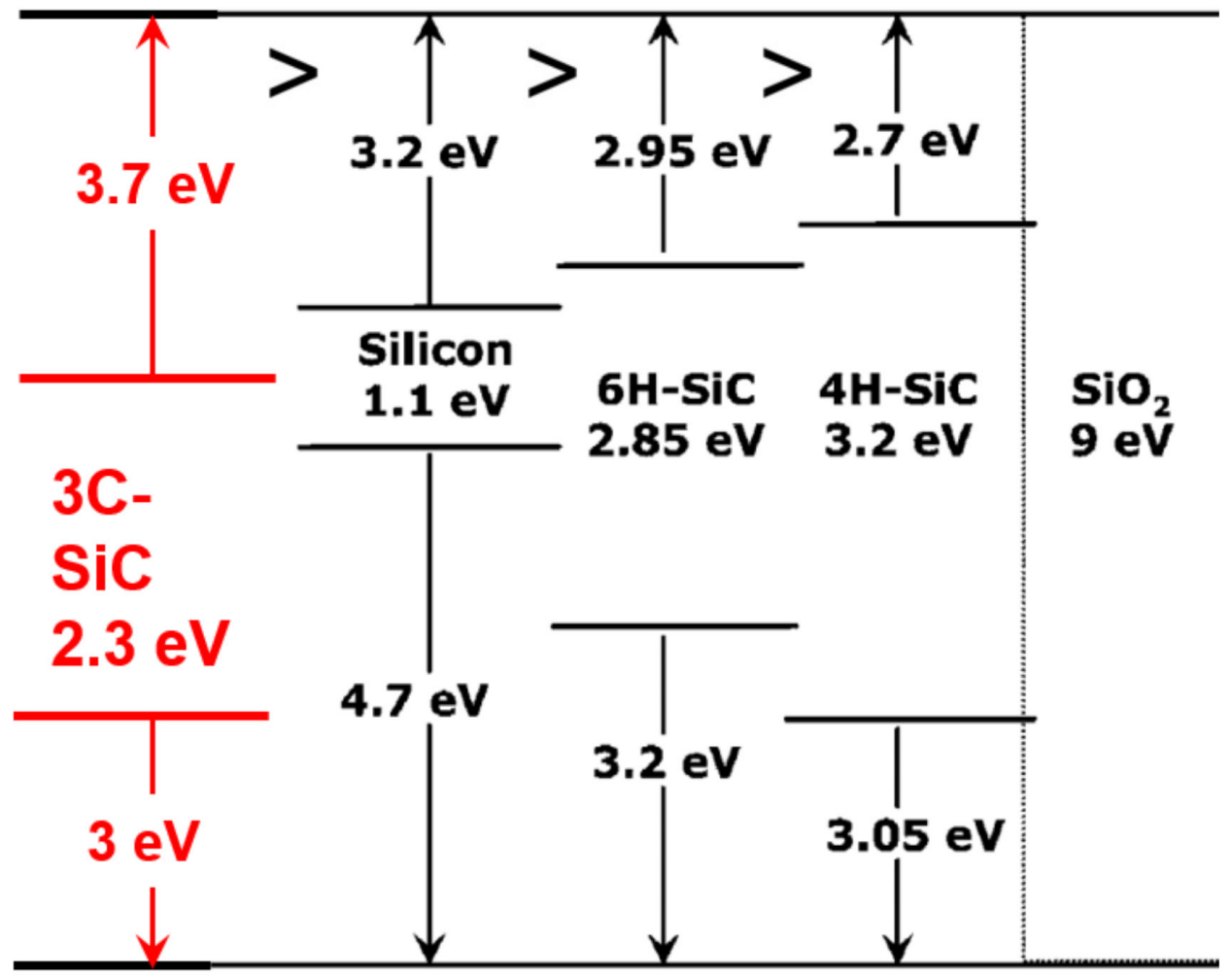

Figure 1. Major power semiconductors' band structure for 3C-SiC, $4 \mathrm{H}-\mathrm{SiC}, 6 \mathrm{H}-\mathrm{SiC}$ and silicon, illustrating band offsets with silicon dioxide $\left(\mathrm{SiO}_{2}\right)$.

Fardi and Van Zeghbroeck [13] developed an empirical breakdown field model based on the breakdown voltage and field values that were obtained from published experimental data $[14,15]$. This proved to be more than adequate for 3C-SiC device design, having matched electrical breakdown characteristics to many published reports. Moreover, the model has been utilised in commercial 2-dimensional device design suites [16-18]. Fitting these impact ionisation coefficients to the electric field and substituting into the impact ionisation integral leads to closed-form solutions of the breakdown voltage and depletion layer width. These material parameters allow for the initial stages of power device design. The closed-form solutions for the breakdown voltage and parallel-plane depletion region width are given as:

$$
\begin{aligned}
& B V_{P P}=7.88 \times 10^{14} N_{D}{ }^{-3 / 4} \\
& W_{P P}=9.12 \times 10^{10} N_{D}{ }^{-7 / 8}
\end{aligned}
$$

where $B V_{P P}$ is the breakdown voltage, $N_{D}$ is the doping concentration and $W_{P P}$ is the parallel-plane depletion region width. The breakdown voltage and depletion region widths predicted by Equations (2) and (3), respectively, are shown in Figure 2. 


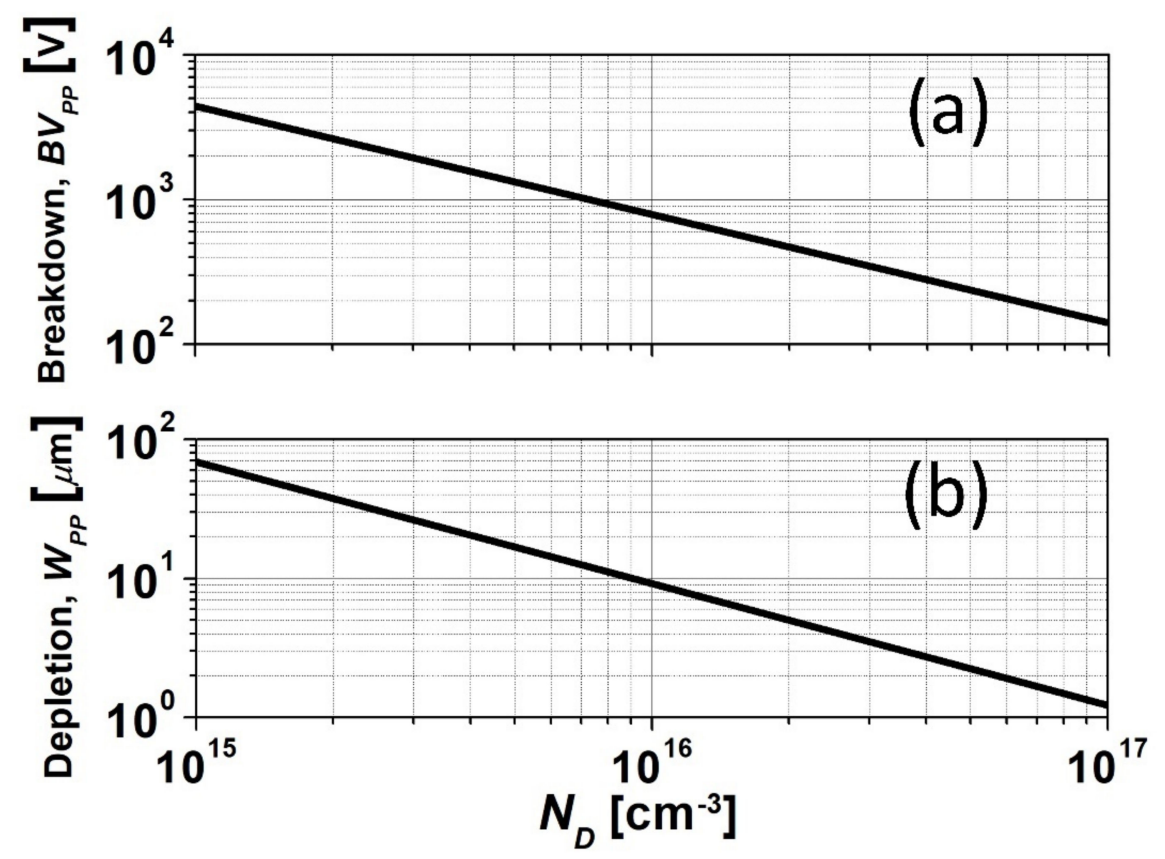

Figure 2. (a) Parallel plane breakdown voltage $\left(B V_{P P}\right)$ and (b) depletion width $\left(W_{P P}\right)$ as a function of doping $\left(N_{D}\right)$ for 3C-SiC.

\section{Processing Technology for 3C-SiC}

\subsection{Schottky Contact}

One of the main challenges in the processing of electronic devices based on $3 \mathrm{C}-\mathrm{SiC}$ is the achievement of good quality rectifying contacts, i.e., with almost ideal characteristics and reasonably low leakage current. Several works investigated the properties of Schottky contacts on n-type 3C-SiC over the last three decades. In particular, as summarized in Table 2, most of these works have been performed on 3C-SiC layers grown on Si substrates, using high work-function Schottky contact metals (e.g., Au or Pt). However, the experimental values of the Schottky Barrier Height (SBH), as determined by I-V or C-V measurements, typically lie below $1 \mathrm{eV}$, i.e., which are much lower than the theoretical predictions of the Schottky-Mott theory.

Eriksson et al. [19] demonstrated the key role of the material quality on the properties of the metal/3C-SiC contacts, showing that double position boundaries (DPB) in 3C$\mathrm{SiC}$ layers grown onto on-axis $4 \mathrm{H}-\mathrm{SiC}$ can be "killer defects" in large area devices that compromise the functionality of the rectifying barrier [20]. In this work, a novel approach based on Conductive Atomic Force Microscopy (C-AFM) was proposed to characterize Schottky barriers on 3C-SiC in small area devices, establishing a direct relation between the electrical properties of the barrier and the contact area. In particular, reducing the size of the contact resulted in a drastic increase in the measured $\mathrm{Au} / 3 \mathrm{C}-\mathrm{SiC}$ barrier height, until reaching a value of $1.39 \mathrm{eV}$ for a diode radius of $5 \mu \mathrm{m}$, thus demonstrating that the poor rectifying behaviour was due to the high defects density in the material [19].

More recently, using a similar nanoscale approach on 3C-SiC layers grown on $\mathrm{Si}$, Giannazzo et al. [21] confirmed that the device yield, defined as the fraction of diodes with a leakage current lower than $10 \mu \mathrm{A} / \mathrm{cm}^{2}$ (see Figure $3 \mathrm{a}, \mathrm{b}$ ) increases with decreasing the device area. Moreover, this work better clarified the role of specific defects by direct probing of the 3C-SiC surface by C-AFM (see Figure 3c-e). In particular, these measurements showed that antiphase boundaries (APBs) are the main defects responsible for reverse leakage current, while both APBs and stacking faults (SFs) worked as preferential current paths under forward bias of the contact. 
(a)

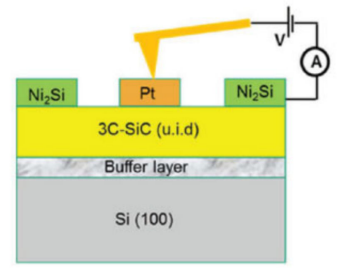

(b)

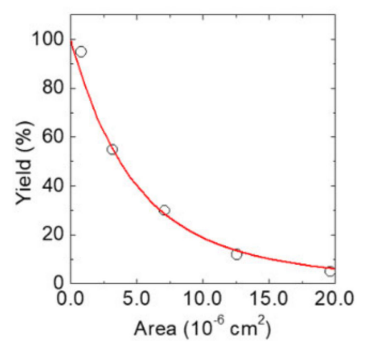

(c)

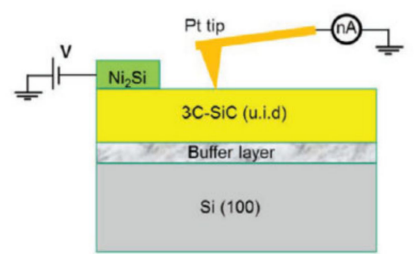

(d)

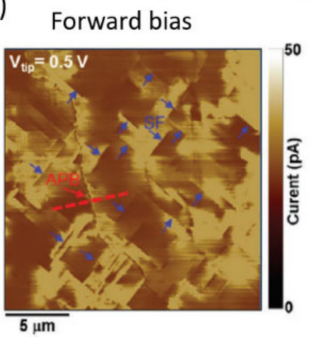

(e)

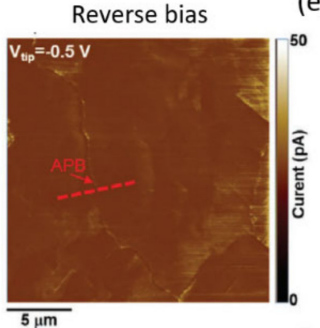

Figure 3. (a) Schematic of the C-AFM set-up to probe Pt/3C-SiC Schottky diodes of different areas. (b) Percentage of the diodes (yield) with a reverse leakage lower than $10 \mu \mathrm{A} \mathrm{cm}^{-2}$, as a function of diode area. (c) Schematic of the C-AFM set-up to probe the 3C-SiC surface and current maps acquired under forward bias (d) and reverse bias (e). Adapted with permission from Ref. [21]. Copyright (C) 2021 Wiley VCH.

Table 2. Collection of literature results on Schottky contacts on 3C-SiC materials.

\begin{tabular}{|c|c|c|c|c|c|c|}
\hline Metal & $\begin{array}{c}\text { 3C-SiC } \\
\text { Orientation }\end{array}$ & $\begin{array}{l}\text { Growing } \\
\text { Substrate }\end{array}$ & $\begin{array}{c}\text { Schottky Barrier } \\
\text { Height }(\mathrm{eV})\end{array}$ & Ideality Factor & Extraction Method & Ref. \\
\hline $\mathrm{Au}$ & 100 & $\mathrm{Si}$ & 1.15 & N.A. & $\mathrm{C}-\mathrm{V}$ & [22] \\
\hline $\mathrm{Au}$ & 100 & $\mathrm{Si}$ & 1.2 & 1.5 & $\mathrm{C}-\mathrm{V}$ & [23] \\
\hline $\mathrm{Au}$ & \multirow{2}{*}{111,100} & \multirow{2}{*}{$\mathrm{Si}$} & $1.0-1.6$ & \multirow{2}{*}{ N.A. } & \multirow{2}{*}{$\mathrm{C}-\mathrm{V}$} & \multirow{2}{*}{ [24] } \\
\hline $\mathrm{Pt}$ & & & $1.3-1.8$ & & & \\
\hline $\mathrm{Pt}$ & 100 & $\mathrm{Si}$ & $\begin{array}{c}0.95 \text { (as dep) } \\
-1.35\left(800^{\circ} \mathrm{C}\right)\end{array}$ & N.A. & $\mathrm{C}-\mathrm{V}$ & [25] \\
\hline $\mathrm{Pd}$ & \multirow{3}{*}{100} & \multirow{3}{*}{$\mathrm{Si}$} & $0.92,0.95$ & \multirow{3}{*}{ N.A. } & \multirow{3}{*}{$C-V$, XPS } & \multirow{3}{*}{ [26] } \\
\hline $\mathrm{Au}$ & & & $0.87,0.78$ & & & \\
\hline Co & & & $0.73,0.69$ & & & \\
\hline $\mathrm{Au}$ & 100 & $\mathrm{Si}$ & $0.47-0.69$ & $1.58-2.30$ & $\mathrm{I}-\mathrm{V}$ & [27] \\
\hline $\mathrm{Pd}$ & 100 & $\mathrm{Si}$ & $0.42-0.60$ & $3.02-5.28$ & $\mathrm{I}-\mathrm{V}$ & [28] \\
\hline $\mathrm{Ti}$ & \multirow{3}{*}{100} & \multirow{3}{*}{ 3C-SiC } & 0.4, N.A. & \multirow{3}{*}{ N.A. } & \multirow{3}{*}{$\mathrm{I}-\mathrm{V}, \mathrm{C}-\mathrm{V}$} & \multirow{3}{*}{ [29] } \\
\hline $\mathrm{Au}$ & & & $0.67,0.65$ & & & \\
\hline $\mathrm{Ni}$ & & & $0.56,0.54$ & & & \\
\hline $\mathrm{Au}$ & 111 & $4 \mathrm{H}-\mathrm{SiC}$ & $0.7,1.39$ & $>2$ & I-V, I-V by C-AFM & [19] \\
\hline $\mathrm{Pt}$ & 100 & 3C-SiC & $\begin{array}{c}0.77 \text { (as dep) } \\
-1.12\left(500^{\circ} \mathrm{C}\right)\end{array}$ & N.A. & & [30] \\
\hline $\mathrm{Au}$ & 111 & $4 \mathrm{H}-\mathrm{SiC}$ & $0.73-0.76$ & N.A. & I-V by C-AFM & [31] \\
\hline
\end{tabular}

Clearly, all these results indicate that a significant improvement of the material quality (namely, a reduction of specific defects' density) remains the only possible route for the achievement of operational Schottky contacts on 3C-SiC materials suitable for power electronics applications. 


\subsection{Ion Implantation and Activation}

High impurity doping is necessary for low ohmic contact and sheet resistance in 3C-SiC power devices. The most commonly used dopants for 3C-SiC are nitrogen or phosphorus for n-type, and mainly aluminium for p-type.

The low diffusivity of typical dopants in SiC below $1800{ }^{\circ} \mathrm{C}$ [32] means that highly doped selective regions of $\mathrm{SiC}$ power devices are often achieved by ion implantation. As implanted dopant species are nearly always interstitial (not chemically bonded), they are therefore electrically inert. Therefore, an extra post implant annealing (PIA) step is typically deployed to repair the lattice damage and place the implanted dopants into their correct substitutional positions. This is referred to as 'activation'. Extremely high temperatures are required for the $\mathrm{SiC} \mathrm{PIA}$; above $1400^{\circ} \mathrm{C}[33,34]$ is common for n-type $\mathrm{SiC}$ and higher still $\left(>1600^{\circ} \mathrm{C}\right)$ for $\mathrm{p}$-type [35-37]. The higher p-type PIA temperature is required because acceptors sit deeper in the band gap than donors, and are consequently more challenging to activate. Regarding 3C-SiC, the most common form is grown heteroepitaxially on $\mathrm{Si}$. As a consequence, these activation annealing temperatures are often limited to $1412{ }^{\circ} \mathrm{C}(\mathrm{Si}$ melting point). Performing the ion implantation at a higher temperature helps to reduce the induced lattice damage; thus, it is often applied for high dose implantations. Since the ion implantation induced lattice damage increases with the number of dopants per unit volume (namely the dose), hot implants are almost mandatory when the implant concentration goes above $10^{19} \mathrm{~cm}^{-3}$ [38].

High temperature PIA also causes a rough semiconductor surface, which is enhanced within implanted regions and can degrade the performance of critical interfaces such as Schottky contacts and MOSFET channels [39-41]. A graphite capping layer, demonstrated to be effective up to $1800{ }^{\circ} \mathrm{C}$ [35], is often utilised to protect the SiC surface during the PIA and reduce the resulting roughness. Comparing the few examples in the literature, n-type implanted $3 \mathrm{C}-\mathrm{SiC}$ have been extensively studied for varying annealing conditions $\left(1150{ }^{\circ} \mathrm{C}\right.$ to $\left.1400{ }^{\circ} \mathrm{C}\right)$ both with a graphite capping layer [42] and without [43,44]. It was shown that there was little advantage demonstrated when using a graphite cap, likely due to the annealing temperature (below $1400{ }^{\circ} \mathrm{C}$ due to the Si substrate) not being high enough to roughen the surface. In [45], it was shown that by combing the use of hot implant and pulsed excimer laser processing, which only anneals the surface region, 3C-SiC crystal damage due to implantation can be effectively repaired without degrading the surface morphology (energy density $0.2444 \mathrm{~J} / \mathrm{cm}^{2}$ at $10 \mathrm{~Hz}$ ), thus providing an alternative solution that allows high temperature PIA to be conducted on Si substrates.

Despite resulting in a rougher surface, a higher temperature is preferred in favour of a higher dopant activation rate. Attributed to a smaller band gap, thus a shallower donor level $(55 \mathrm{meV})$, the activation of n-type dopants in $3 \mathrm{C}-\mathrm{SiC}$ is easier than in $4 \mathrm{H}$ $\mathrm{SiC}(80-130 \mathrm{meV})$ [46]. Studies on n-type 3C-SiC suggest that nitrogen has advantages over phosphorous for use as an n-type dopant, with both fewer defects and lower resistivity achieved [42]. Compared with the $\mathrm{N}$ saturation density in 4H-SiC (around $5 \times 10^{19} \mathrm{~cm}^{-3}$ ) [47], the level in 3C-SiC turns out to be similar at around $7 \times 10^{19} \mathrm{~cm}^{-3}$ [48]. With the valence band aligned to other polytypes, the deep acceptor level issue still exists for $3 \mathrm{C}-\mathrm{SiC}$. Adding to the limited processing temperature, p-type implant and activation has long been an issue for 3C-SiC-on-Si $[38,49]$. In recent years, the developments on free standing $3 \mathrm{C}-\mathrm{SiC}$ materials $[50,51]$ make PIA temperatures above $1400{ }^{\circ} \mathrm{C}$ possible, thus facilitating a significant step forward in $3 \mathrm{C}-\mathrm{SiC}$ power device fabrication. However, the knowledge of p-type 3C-SiC ion implantation and activation is very limited and requires further investigation. Table 3 summarises some past results published on the ion implantation and activation of dopants in 3C-SiC. 
Table 3. A summary of literature data on the ion implantation and activation of 3C-SiC.

\begin{tabular}{|c|c|c|c|c|}
\hline Material & Implantation & PIA & Activation Rate & Ref. \\
\hline \multicolumn{5}{|c|}{ N-Type } \\
\hline \multirow{3}{*}{$\begin{array}{c}2 \times 10^{17} \mathrm{~cm}^{-3} \mathrm{p} \text {-type } \\
3 \mathrm{C}-\mathrm{SiC}(100) / \mathrm{Si}\end{array}$} & $\mathrm{RT}^{1}, \mathrm{~N}$, peak $5 \times 10^{19} / 5 \times 10^{20} \mathrm{~cm}^{-3}$ & \multirow{3}{*}{ None } & $0.44 \% / 0.55 \%$ & \multirow{3}{*}{ [52] } \\
\hline & $400^{\circ} \mathrm{C}, \mathrm{N}$, peak $5 \times 10^{19} \mathrm{~cm}^{-3}$ & & $1.35 \%$ & \\
\hline & $\begin{array}{c}800^{\circ} \mathrm{C}, \mathrm{N}, \text { peak } 5 \times 10^{19} / 5 \times \\
10^{20} \mathrm{~cm}^{-3}\end{array}$ & & $15 \% / 50.8 \%$ & \\
\hline \multirow{5}{*}{$\begin{array}{c}1 \times 10^{18} \mathrm{~cm}^{-3} \mathrm{p} \text {-type } \\
3 \mathrm{C}-\mathrm{SiC}(100) / \mathrm{Si}\end{array}$} & $800{ }^{\circ} \mathrm{C}, \mathrm{N}$, peak $5 \times 10^{19} \mathrm{~cm}^{-3}$ & \multirow{5}{*}{ None } & $12.4 \%$ & \multirow{5}{*}{ [53] } \\
\hline & $900^{\circ} \mathrm{C}, \mathrm{N}$, peak $5 \times 10^{19} \mathrm{~cm}^{-3}$ & & $14.8 \%$ & \\
\hline & $100{ }^{\circ} \mathrm{C}, \mathrm{N}$, peak $5 \times 10^{19} \mathrm{~cm}^{-3}$ & & $18.4 \%$ & \\
\hline & $1100^{\circ} \mathrm{C}, \mathrm{N}$, peak $5 \times 10^{19} \mathrm{~cm}^{-3}$ & & $36.0 \%$ & \\
\hline & $1200{ }^{\circ} \mathrm{C}, \mathrm{N}$, peak $5 \times 10^{19} \mathrm{~cm}^{-3}$ & & $52.2 \%$ & \\
\hline $\begin{array}{c}1 \times 10^{16} \mathrm{~cm}^{-3} \text { p-type } \\
3 C-\operatorname{SiC}(100)\end{array}$ & $\mathrm{RT}, \mathrm{N}$, peak $1 \times 10^{20} \mathrm{~cm}^{-3}$ & $10 \mathrm{~min}$ in $\mathrm{Ar}$ at $1500^{\circ} \mathrm{C}$ & $68 \%$ & [49] \\
\hline $\begin{array}{c}1 \times 10^{16} \mathrm{~cm}^{-3} \text { p-type } \\
3 C-\operatorname{SiC}(100)\end{array}$ & $\mathrm{RT}$, N, peak $6 \times 10^{19} \mathrm{~cm}^{-3}$ & $10 \mathrm{~min}$ in $\mathrm{Ar}$ at $1400^{\circ} \mathrm{C}$ & $80 \%$ & [54] \\
\hline \multirow{2}{*}{$\begin{array}{c}<1 \times 10^{16} \mathrm{~cm}^{-3} \mathrm{n} \text {-type } \\
3 \mathrm{C}-\mathrm{SiC}(100) / \mathrm{Si}\end{array}$} & \multirow{2}{*}{$\mathrm{RT}, \mathrm{N}$, peak $5 \times 10^{20} \mathrm{~cm}^{-3}$} & $1 \mathrm{~h}$ in $\mathrm{Ar}$ at $1150^{\circ} \mathrm{C}$ & $6.5 \%$ & \multirow{2}{*}{ [46] } \\
\hline & & $1 \mathrm{~h}$ in $\mathrm{Ar}$ at $1350^{\circ} \mathrm{C}$ & $13 \%$ & \\
\hline \multirow{3}{*}{$\begin{array}{c}<1 \times 10^{16} \mathrm{~cm}^{-3} \mathrm{n} \text {-type } \\
3 \mathrm{C}-\mathrm{SiC}(100) / \mathrm{Si}\end{array}$} & \multirow{3}{*}{$\mathrm{RT}, \mathrm{N}$, peak $5 \times 10^{19} \mathrm{~cm}^{-3}$} & $1 \mathrm{~h}$ in $\mathrm{Ar}$ at $1150^{\circ} \mathrm{C}$ & $40 \%$ & \multirow{3}{*}{ [44] } \\
\hline & & $1 \mathrm{~h}$ in $\mathrm{Ar}$ at $1350^{\circ} \mathrm{C}$ & $57 \%$ & \\
\hline & & $1 \mathrm{~h}$ in $\mathrm{Ar}$ at $1400^{\circ} \mathrm{C}$ & $100 \%$ & \\
\hline $\begin{array}{c}<1 \times 10^{16} \mathrm{~cm}^{-3} \mathrm{n} \text {-type } \\
3 \mathrm{C}-\mathrm{SiC}(100 / \mathrm{Si}\end{array}$ & $\mathrm{RT}, \mathrm{N}$, peak $5 \times 10^{19} / 5 \times 10^{20} \mathrm{~cm}^{-3}$ & $1 \mathrm{~h}$ in $\mathrm{Ar}$ at $1350{ }^{\circ} \mathrm{C}$ & $60 \% / 17 \%$ & [55] \\
\hline $\begin{array}{c}<1 \times 10^{16} \mathrm{~cm}^{-3} \mathrm{n} \text {-type } \\
3 \mathrm{C}-\mathrm{SiC}(100 / \mathrm{Si}\end{array}$ & $\mathrm{RT}, \mathrm{N}$, peak $1.5 \times 10^{19} / 6 \times 10^{20} \mathrm{~cm}^{-3}$ & $1 \mathrm{~h}$ in $\mathrm{Ar}$ at $1375^{\circ} \mathrm{C}$ & $100 \% / 12 \%$ & [49] \\
\hline \multicolumn{5}{|c|}{ P-type } \\
\hline $\begin{array}{c}2.8 \times 10^{16} \mathrm{~cm}^{-3} \mathrm{n} \text {-type } \\
3 \mathrm{C}-\mathrm{SiC}(100) / \mathrm{Si}\end{array}$ & $\begin{array}{l}\text { RT and } 850^{\circ} \mathrm{C}, \mathrm{Al} \text { and } \mathrm{B} \text {, peak } 5 \times \\
10^{19}-1 \times 10^{20} \mathrm{~cm}^{-3}\end{array}$ & $10 \min$ in $\mathrm{N}_{2}$ at $1200^{\circ} \mathrm{C}$ & $\begin{array}{l}\text { Too low, n-type } \\
\text { behaviour }\end{array}$ & [50] \\
\hline $\begin{array}{c}<1 \times 10^{16} \mathrm{~cm}^{-3} \mathrm{n} \text {-type } \\
3 \mathrm{C}-\mathrm{SiC}(100) / \mathrm{Si}\end{array}$ & $500^{\circ} \mathrm{C}, \mathrm{Al}$, peak $1 \times 10^{20} \mathrm{~cm}^{-3}$ & $\begin{array}{l}317-546 \mathrm{~h} \text { in } \mathrm{Ar} \text { at } 1300 \\
{ }^{\circ} \mathrm{C}\end{array}$ & Weak p-type behaviour & [38] \\
\hline
\end{tabular}

\subsection{Ohmic Contact}

Due to the requirement of an extra PIA process, achieving ohmic contacts on implanted regions is more difficult than on epilayers. As is the case in $4 \mathrm{H}-\mathrm{SiC}$ [56], this is particularly true for p-type 3C-SiC because the acceptor levels are deeper, as previously mentioned. Attributed to a lower conduction band edge ( $3.8 \mathrm{eV}$ from vacuum level), the theoretical $\mathrm{SBH}$ between $3 \mathrm{C}-\mathrm{SiC}$ and commonly used metals is $0.9 \mathrm{eV}$ lower than for $4 \mathrm{H}-\mathrm{SiC}$. This is convenient for n-type ohmic contact fabrication, while p-type remains as challenging as in other polytypes. Most work on $\mathrm{SiC}$ ohmic contacts is divided into three topics, namely surface preparation, contact metal, and post metallisation annealing (PMA).

The 3C-SiC epilayer surface roughness can vary significantly, from as low as $1 \mathrm{~nm}$ depending on the growth technique [43] to high values reaching tens of $\mathrm{nm}$ [57]. To achieve a relatively smooth semiconductor surface for ohmic contact fabrication, chemical mechanical polishing (CMP) is often used prior to any further processing. Noh et al. [58] show that the RMS surface roughness reduced from $\approx 20 \mathrm{~nm}$ to $\approx 7.5 \mathrm{~nm}$. Consequently, the ohmic contact resistivity $\rho_{c}$ was reduced by an order of magnitude, from $8.6 \times 10^{-1} \Omega \mathrm{cm}^{2}$ to $2.8 \times 10^{-2} \Omega \mathrm{cm}^{2}$. As alluded to previously, practical device fabrication requires a high temperature (above $1400^{\circ} \mathrm{C}$ ) PIA treatment, which has been shown to degrade the 
surface following initial CMP. In [43], a detailed discussion was reported around the PIA effects on 3C-SiC surface morphology and its correlation to the resulting $\rho_{c}$ values. It was communicated that although severe damage to the surface can limit performance, the $\rho_{c}$ value will not be seriously affected given that the surface roughness value remains below $10 \mathrm{~nm}$.

Many metals or metal stacks, including Al [54,59-61], Ti [54,59-61], Ni [37,54,57,58,60-63], $\mathrm{Ni} / \mathrm{Ti}$ [43,55,61], Au/Ti [61], Pt [63], W [37], and TiW [64], have been analysed for 3C-SiC n-type ohmic contact fabrication. It was observed that $\mathrm{Al}$ contacts typically display the lowest $\rho_{c}$, which was explained by the near-zero SBH between $\mathrm{Al}$ and $3 \mathrm{C}-\mathrm{SiC}(\sim 0 \mathrm{eV})$ compared to $\mathrm{Ti}(0.4 \mathrm{eV})$ and $\mathrm{Ni}(0.55 \mathrm{eV})$ [54]. Nonetheless, both Ti and $\mathrm{Al}$ are readily oxidised in air, with $\mathrm{Al}$ characterised by a melting point below $600{ }^{\circ} \mathrm{C}$. Conversely, Ni demonstrates a slow rate of oxidation at room temperature combined with a very high melting point. Although Ni reacts with $\mathrm{SiC}$ at temperatures higher than $50{ }^{\circ} \mathrm{C}$, the Ni silicide microstructure helps to reduce the $\mathrm{SBH}$. This in turn leads to a lower $\rho_{c}$. Consequently, $\mathrm{Ni}$ is the most commonly utilised metal contact to n-type SiC.

The effects of PMA on ohmic contacts fabricated on n-type implanted 3C-SiC (Figure 4a) shows a continuous reduction of contact resistivity with increasing annealing temperature up to $1000{ }^{\circ} \mathrm{C}$, above which the resistance increases. Details of the silicide formation are shown by XRD analysis in Figure $4 \mathrm{~b}$. It can be inferred that between $50{ }^{\circ} \mathrm{C}$ and $600{ }^{\circ} \mathrm{C}$, a coexistence of $\mathrm{Ni}_{2} \mathrm{Si}$ (121) and $\mathrm{Ni}_{31} \mathrm{Si}_{12}$ (300) is present. The $\mathrm{Ni}_{31} \mathrm{Si}_{12}$ (300) peak gradually diminishes at higher temperature, while the $\mathrm{Ni}_{2} \mathrm{Si}(002)$ becomes prominent and enhances continuously to temperatures reaching $1100{ }^{\circ} \mathrm{C}$. Noting that $\mathrm{Ni}_{2} \mathrm{Si}(121)$ is readily formed at $600{ }^{\circ} \mathrm{C}$, with no other noticeable phases above that temperature, the $\mathrm{Ni}_{2} \mathrm{Si}(002)$ enhanced phase could explain the contact resistance reduction from $800^{\circ} \mathrm{C}$ to $1000^{\circ} \mathrm{C}$. It is worth mentioning that, due to the very low $\mathrm{SBH}$ of highly doped n-type $3 \mathrm{C}$-SiC/metal interface, as-deposited ohmic contacts can be obtained without PMA processing [59,65]. This makes it possible to integrate $\mathrm{SiC}$ transistor technologies with other low temperature technologies, such as atomic layer deposited high $\mathrm{k}$ dielectrics (e.g., $\mathrm{HfO}_{2}$ or $\mathrm{Al}_{2} \mathrm{O}_{3}$ ) with relatively low growth temperatures and classic wafer bonded or heterojunction devices.
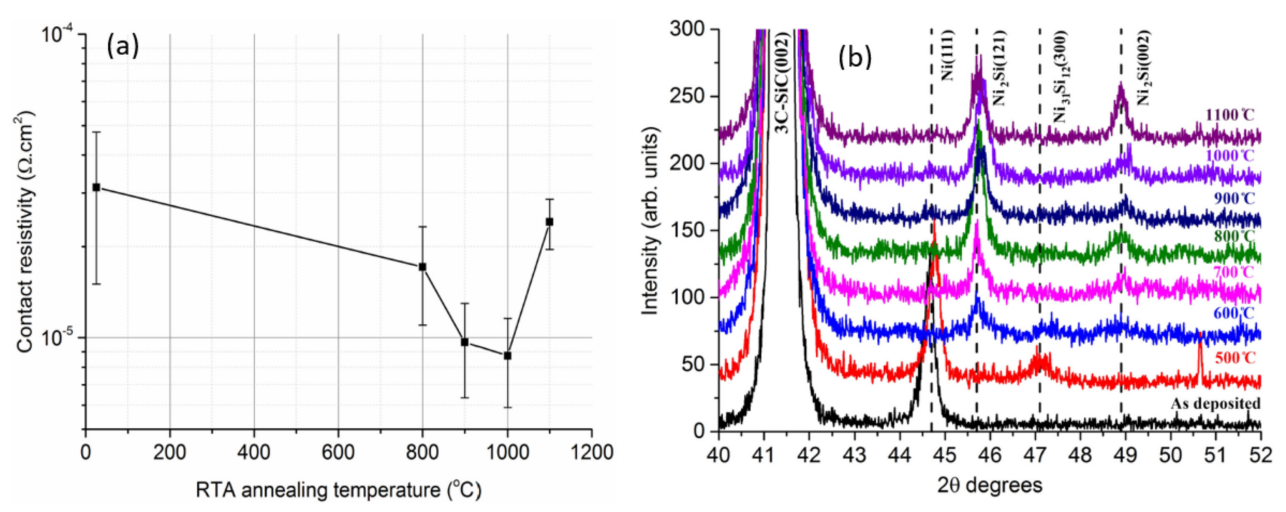

Figure 4. (a) Specific contact resistance dependence on the PMA temperature and, (b) XRD measurements of metal/3C-SiC $\left(6 \times 10^{20} \mathrm{~cm}^{-3}\right)$ interface after various PMA temperatures indicating silicide formation. Contact was fabricated by depositing (Ti30 nm/Ni100 nm) on $5 \times 10^{20} \mathrm{~cm}^{-3} \mathrm{~N}$ implanted 3C-SiC.

Compared to n-type 3C-SiC, even less is known about p-type 3C-SiC ohmic contacts. As with $4 \mathrm{H}-\mathrm{SiC}$, $\mathrm{Al}$ based alloys are most commonly used for p-type ohmic contact since very often $\mathrm{Al}$ is also the doping species. A Ti interlayer is often applied not only to improve the adhesion, but the TiC product after PMA also helps to reduce the contact resistance $[36,66]$.

Among the very limited data, the lowest specific contact resistances $\left(10^{-5}-10^{-4} \Omega \mathrm{cm}^{2}\right)$ are obtained from trials made on p-type epilayers [66,67], which eliminates the issue of acceptor activation. However, when fabricating power devices such as MOSFETs, it is 
crucial to obtain ohmic contacts on selective highly doped, mostly implanted p+ regions. It is reported in [38] that, on $3 \mathrm{C}-\mathrm{SiC}$ with a $\mathrm{Si}$ substrate, a hot implant $\left(500^{\circ} \mathrm{C}\right)$ with high $\mathrm{Al}$ concentration $\left(1 \times 10^{20} \mathrm{~cm}^{-3}\right)$ together with very long duration $(>300 \mathrm{~h})$ PIA at $1300{ }^{\circ} \mathrm{C}$ had to be performed to achieve ohmic contacts, and even so, the resultant $\rho_{c}$ was still high, around the $10^{-2} \Omega \mathrm{cm}^{2}$ level. More recently, p-type ohmic contacts (Figure $5 \mathrm{a}$ ) on Al hot implanted $\left(600^{\circ} \mathrm{C}, 1 \times 10^{20} \mathrm{~cm}^{-3}\right)$ free standing $3 \mathrm{C}-\mathrm{SiC}$ have been reported. By increasing the PIA temperature treatment to $1700^{\circ} \mathrm{C}$, a dramatic reduction in annealing time was required-down to $2 \mathrm{~h}$. Even though the $\rho_{c}$ value is still relatively high $\sim 10^{-3} \Omega \mathrm{cm}^{2}$, it is promising since the contacts were fabricated on a very rough surface (Figure $5 b$ ), which can be further improved either by optimising the $3 \mathrm{C}-\mathrm{SiC}$ growth process or additional polishing treatments. Table 4 provides a survey of the literature results for ohmic contact processing on $3 \mathrm{C}-\mathrm{SiC}$, mostly n-type.
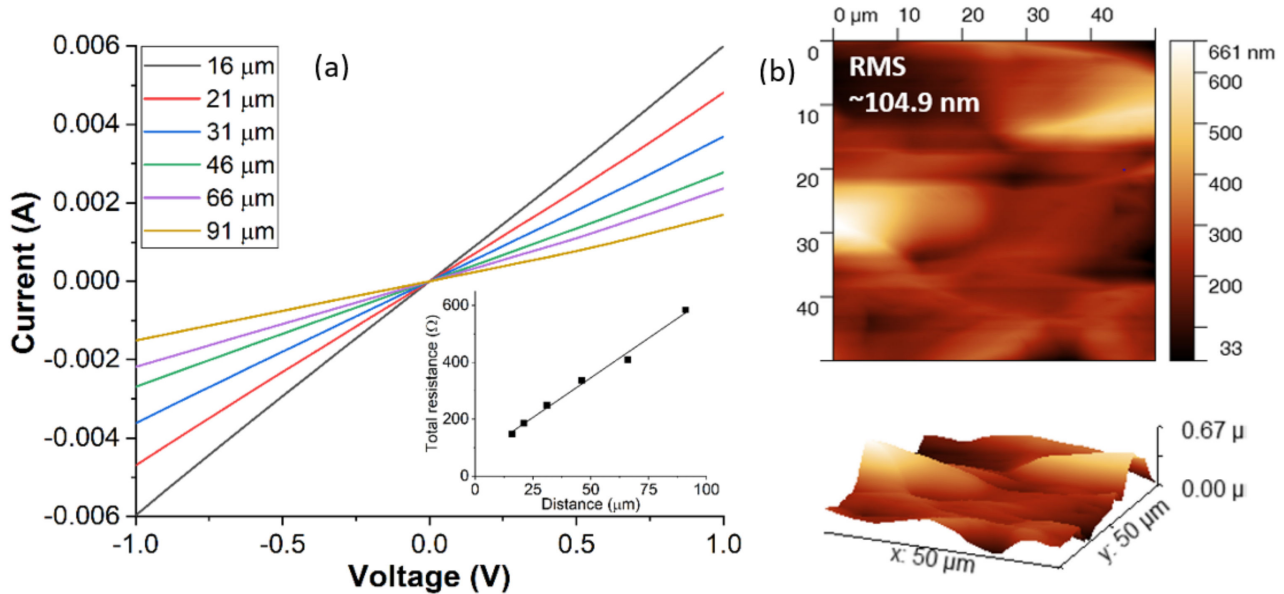

Figure 5. (a) I-V characteristic ohmic contact (Ni/Al/Ti) fabricated on $\mathrm{Al}$ implanted free standing 3C-Si and, (b) surface morphology of the free standing 3C-SiC by AFM.

Table 4. A summary of literature data on the fabrication of 3C-SiC ohmic contact.

\begin{tabular}{|c|c|c|c|c|}
\hline Contact & Doping $\left(\mathrm{cm}^{-3}\right)$ & PMA Conditions & $\rho_{c}\left(\Omega \mathrm{cm}^{2}\right)$ & Ref. \\
\hline \multicolumn{5}{|c|}{ N-Type } \\
\hline \multirow{7}{*}{$\mathrm{Al}$} & $5 \times 10^{18} \mathrm{~N}$ implanted & \multirow{4}{*}{ As-deposited } & $1 \times 10^{-4}$ & \multirow{4}{*}{ [59] } \\
\hline & $3 \times 10^{19} \mathrm{~N}$ implanted & & $6 \times 10^{-5}$ & \\
\hline & $1 \times 10^{20} \mathrm{~N}$ implanted & & $5 \times 10^{-5}$ & \\
\hline & $3 \times 10^{20} \mathrm{~N}$ implanted & & $1.3 \times 10^{-5}$ & \\
\hline & $6 \times 10^{19} \mathrm{~N}$ implanted & As-deposited $/ 500^{\circ} \mathrm{C}$ & $5 \times 10^{-7} / 6 \times 10^{-5}$ & [54] \\
\hline & $6 \times 10^{18} \mathrm{~N}$ implanted & $300{ }^{\circ} \mathrm{C}$ & $5 \times 10^{-7}$ & [61] \\
\hline & $1 \times 10^{17} \mathrm{~N}$ doped epi & As deposited $/ 500^{\circ} \mathrm{C}$ & $2 \times 10^{-4} / 1 \times 10^{-4}$ & [37] \\
\hline \multirow{5}{*}{$\mathrm{Ti}$} & $5 \times 10^{18} \mathrm{~N}$ implanted & \multirow{4}{*}{ As-deposited } & $7 \times 10^{-5}$ & \multirow{4}{*}{ [59] } \\
\hline & $3 \times 10^{19} \mathrm{~N}$ implanted & & $4 \times 10^{-5}$ & \\
\hline & $1 \times 10^{20} \mathrm{~N}$ implanted & & $2 \times 10^{-5}$ & \\
\hline & $3 \times 10^{20} \mathrm{~N}$ implanted & & $1.5 \times 10^{-5}$ & \\
\hline & $6 \times 10^{19} \mathrm{~N}$ implanted & As-deposited $/ 500{ }^{\circ} \mathrm{C}$ & $5 \times 10^{-6} / 6 \times 10^{-5}$ & [54] \\
\hline \multirow{4}{*}{$\mathrm{Ni}$} & Not known, N doped epi & $1000^{\circ} \mathrm{C}$ & $3.7 \times 10^{-4}$ & {$[58]$} \\
\hline & $6 \times 10^{19} \mathrm{~N}$ implanted & As-deposited $/ 500{ }^{\circ} \mathrm{C}$ & $2 \times 10^{-5} / 5 \times 10^{-6}$ & [54] \\
\hline & $3 \times 10^{19} \mathrm{~N}$ doped epi & $950{ }^{\circ} \mathrm{C}$ & $1.2 \times 10^{-5}$ & {$[61]$} \\
\hline & $1 \times 10^{17} \mathrm{~N}$ doped epi & As-deposited $/ 500^{\circ} \mathrm{C}$ & $5 \times 10^{-4} / 5 \times 10^{-5}$ & [37] \\
\hline
\end{tabular}


Table 4. Cont.

\begin{tabular}{|c|c|c|c|c|}
\hline Contact & Doping $\left(\mathrm{cm}^{-3}\right)$ & PMA Conditions & $\rho_{c}\left(\Omega \mathrm{cm}^{2}\right)$ & Ref. \\
\hline & $1 \times 10^{20} \mathrm{P}$ implanted & $1000{ }^{\circ} \mathrm{C}$ & $1.4 \times 10^{-5}$ & [61] \\
\hline & Not known, poly crystal epi & As-deposited & $1.6 \times 10^{-6}$ & [65] \\
\hline & $5 \times 10^{17} \mathrm{~N}$ doped epi & $950{ }^{\circ} \mathrm{C}$ & $1.5 \times 10^{-5}$ & {$[57]$} \\
\hline & $1 \times 10^{17} \mathrm{~N}$ doped epi & $950^{\circ} \mathrm{C}$ & $3.7 \times 10^{-3}$ & {$[66]$} \\
\hline \multirow{9}{*}{$\mathrm{Ni} / \mathrm{Ti}$} & $5 \times 10^{19} \mathrm{~N}$ implanted & \multirow{2}{*}{ As-deposited } & $7 \times 10^{-4}$ & \multirow{5}{*}[65]{} \\
\hline & $5 \times 10^{20} \mathrm{~N}$ implanted & & $3 \times 10^{-5}$ & \\
\hline & $1 \times 10^{19} \mathrm{~N}$ implanted & \multirow{3}{*}{$1000^{\circ} \mathrm{C}$} & $2 \times 10^{-4}$ & \\
\hline & $5 \times 10^{19} \mathrm{~N}$ implanted & & $4 \times 10^{-5}$ & \\
\hline & $5 \times 10^{20} \mathrm{~N}$ implanted & & $9 \times 10^{-6}$ & \\
\hline & $5 \times 10^{20} \mathrm{~N}$ implanted & \multirow{2}{*}{$1000^{\circ} \mathrm{C}$} & $8 \times 10^{-6}$ & \multirow{2}{*}{ [43] } \\
\hline & $5 \times 10^{20} \mathrm{P}$ implanted & & $2 \times 10^{-5}$ & \\
\hline & $>10^{20} \mathrm{~N}$ implanted & $1050^{\circ} \mathrm{C}$ & $2 \times 10^{-5}$ & {$[61]$} \\
\hline & $5 \times 10^{19} \mathrm{~N}$ implanted & $1000^{\circ} \mathrm{C}$ & $3.2 \times 10^{-6}$ & {$[55]$} \\
\hline $\mathrm{Au} / \mathrm{Ti}$ & $3 \times 10^{20} \mathrm{~N}$ implanted & $600^{\circ} \mathrm{C}$ & $1.2 \times 10^{-5}$ & {$[61]$} \\
\hline $\mathrm{Pt}$ & Not know, poly crystal N doped epi & As-deposited & $1.2 \times 10^{-5}$ & {$[63]$} \\
\hline $\mathrm{W}$ & $1 \times 10^{17} \mathrm{~N}$ doped epi & As-deposited $/ 500^{\circ} \mathrm{C}$ & $2 \times 10^{-3} / 2 \times 10^{-3}$ & {$[37]$} \\
\hline \multirow{2}{*}{$\mathrm{TiW}$} & Not know, N doped epi & $1000^{\circ} \mathrm{C}$ & $4.6 \times 10^{-4}$ & {$[64]$} \\
\hline & $4 \times 10^{19} \mathrm{~N} / \mathrm{P}$ implanted & As-deposited & ohmic & {$[68]$} \\
\hline \multicolumn{5}{|c|}{ P-type } \\
\hline $\mathrm{Al}$ & \multirow{2}{*}{$1.33 \times 10^{17} \mathrm{Al}$ doped epi } & \multirow{2}{*}{$710^{\circ} \mathrm{C}$} & $1.4 \times 10^{-2}$ & \multirow{2}{*}{ [67] } \\
\hline Al/Poly & & & $3.5 \times 10^{-4}$ & \\
\hline \multirow{3}{*}{$\mathrm{Ni} / \mathrm{Al} / \mathrm{Ti}$} & $5 \times 10^{19} \mathrm{Al}$ doped epi & $950^{\circ} \mathrm{C}$ & $1.8 \times 10^{-5}$ & {$[66]$} \\
\hline & $1 \times 10^{20} \mathrm{Al}$ implanted & $1000^{\circ} \mathrm{C}$ & $10^{-2}$ & {$[38]$} \\
\hline & $1 \times 10^{20} \mathrm{Al}$ implanted & $1000^{\circ} \mathrm{C}$ & $10^{-3}$ & This work \\
\hline
\end{tabular}

\subsection{MOS Processing}

Given the superior electrical performance of $\mathrm{SiC}$ and its capacity to be thermally oxidised, it is not surprising that there are copious amounts of $\mathrm{SiC}$ MOS devices being demonstrated. The commercialised $4 \mathrm{H}-\mathrm{SiC}$ polytype is naturally the most frequently reported. Numerous literature reports suggest that MOS interface traps are similar in nature for all $\mathrm{SiC}$ polytypes [69]. Therefore, studies relating to the $4 \mathrm{H}-\mathrm{SiC} / \mathrm{SiO}_{2}$ interface provide insightful information with respect to the equivalent $3 \mathrm{C}-\mathrm{SiC}$ system.

In [70], reporting around the possible origins of interface traps identified two primary sources; namely, carbon and oxide defects that accumulate at the MOS interface during the oxidation process. The oxide defect-induced traps (also known as "near-interface traps") have much smaller time constants compared to the carbon-clusters. Therefore, oxide defect-induced traps are also known as "fast traps" while the latter are coined "slow traps". A graphic illustration of the carbon cluster model is shown in Figure 6, including the corresponding specified energy levels of the traps. Figure 6 shows the $4 \mathrm{H}-\mathrm{SiC}$ conduction band edge is overwhelmingly impacted by $\pi$-bonded clusters and carbon near-interface traps, with the latter being most dominant. Both trap forms are acceptor-like, therefore negatively charged when occupied, which explains the positive flat band voltage $\left(V_{f b}\right)$ typically detected with respect to $4 \mathrm{H}-\mathrm{SiC}$ MOS devices. In contrast, the $3 \mathrm{C}-\mathrm{SiC}$ conduction band is devoid of near-interface traps due to a narrower band 
gap. However, $3 \mathrm{C}$-SiC is still negatively-impacted by $\pi$-bonded carbon clusters. These (carbon clusters near the $3 \mathrm{C}-\mathrm{SiC}$ conduction band edge) defects are positively charged if occupied as they are donorlike, resulting in a $V_{f b}$ that is negative. Dangling bonds augment the interface defectiveness but are negligible secondary concerns compared to the aforementioned carbon clusters. Consequently, hydrogen annealing is not as effective for $\mathrm{SiC}$ when compared to Si. Alternative methods have been demonstrated for high-quality $\mathrm{SiC} / \mathrm{SiO}_{2}$ interface optimisation.

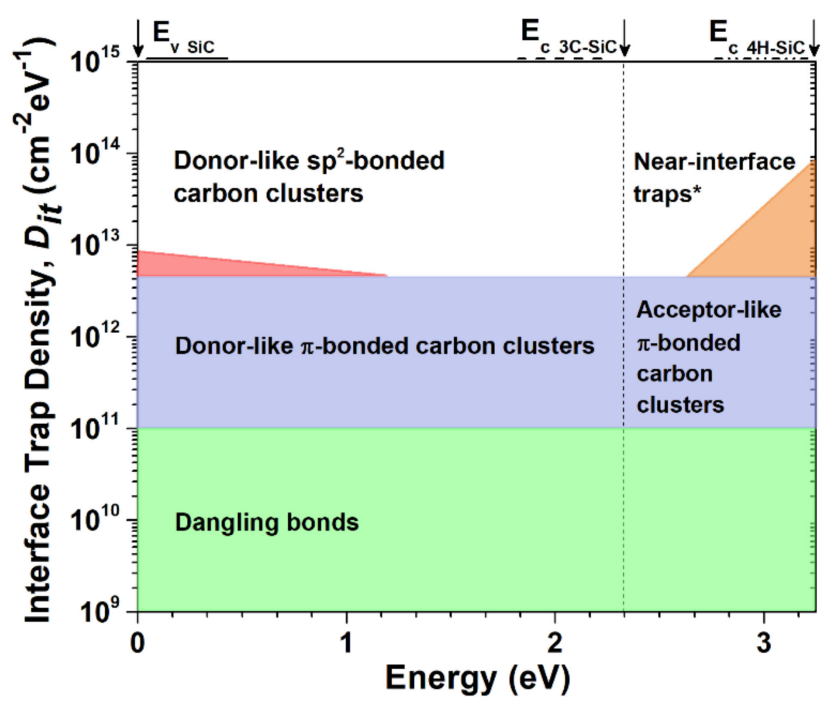

Figure 6. Schematic representation of the "carbon cluster model". Adapted from Ref. [71] with permission from the author (R. Esteve).

Reports focussing on the improvement of the $\mathrm{SiC} / \mathrm{SiO}_{2}$ interface are mainly related to the topic of post oxidation annealing (POA). Former research literature revealed the advantages of including hydrogenation processes either during the (gate) oxidation process or subsequently, via the POA. This has the effect of decreasing the interface trap density $\left(D_{i t}\right)$ in addition to reducing positive fixed charge $\left(Q_{f c}\right)[68,72]$. Consequently, wet oxidation in conjunction with POA is often utilised for 3C-SiC MOSFET fabrication [73,74]. Regarding the nitridation step, extra deep interface traps revealed by double peak conductance spectra were observed from fabricated MOS capacitors via direct $\mathrm{N}_{2} \mathrm{O}$ oxidation and pure $\mathrm{O}_{2}$ oxidation methods on nitrogen implanted films [72,75].

Figure 7 shows the lateral MOSFET transfer curves on $\mathrm{Al}$ implanted $3 \mathrm{C}-\mathrm{SiC} / \mathrm{Si}$ substrates with the gate oxide grown in different atmospheres, but all at the same temperature of $1300{ }^{\circ} \mathrm{C}$ [76]. Due to varying oxide thicknesses, for direct comparison the gate field instead of gate voltage is plotted on the $x$-axis. It can be inferred that the dry oxidized device demonstrates a normally on characteristic with a gate threshold voltage approaching zero. This is in agreement with the previously introduced Carbon Cluster Model, stating that only donor-like states occupy the $3 \mathrm{C}-\mathrm{SiC} / \mathrm{SiO}_{2}$ interface. Since these states are positively charged when vacant, these donor-like states may be responsible for the inherent negative threshold. The nitrided sample is even further shifted in the negative threshold direction due to the counter doping channel effect [77]. The wet oxidized sample has the most positive gate threshold. A combination of $\mathrm{N}_{2} \mathrm{O}$ nitridation and POA (wet) yielded an intermediate threshold field of around $-2 \mathrm{MV} / \mathrm{cm}$. Clearly, the wet oxidation was successful in shifting the device threshold in a more positive manner, either by forcing a reduction in positive fixed oxide charges or via compensating them with additional negative charge. Both wet POA and oxidized processed devices have a peak field-effect mobility $\left(\mu_{F E}\right)$ value in the region of $60 \mathrm{~cm}^{2} / \mathrm{Vs}$, which is the lowest compared with the dry oxidized sample $\left(70 \mathrm{~cm}^{2} / \mathrm{Vs}\right)$ and the $\mathrm{N}_{2} \mathrm{O}$ nitrided sample $\left(90 \mathrm{~cm}^{2} / \mathrm{Vs}\right)$. 


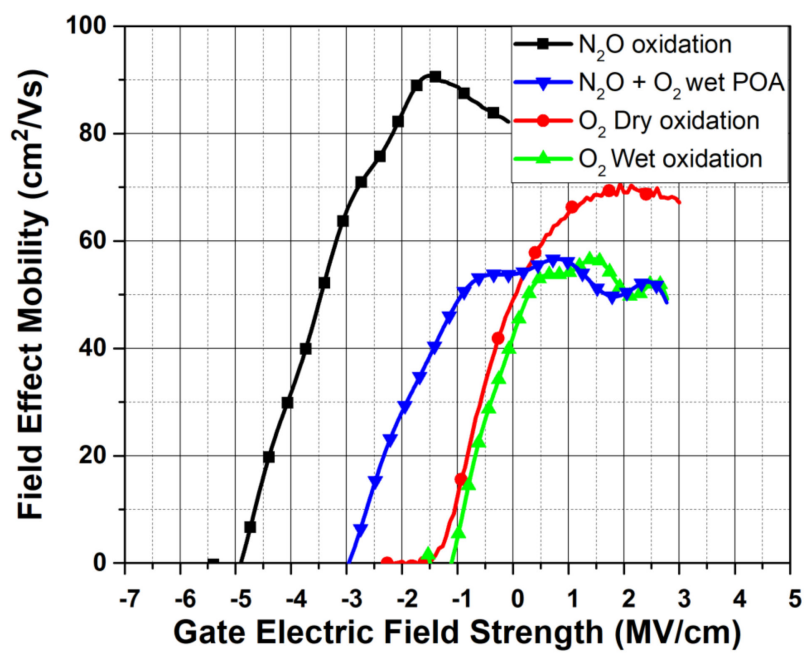

Figure 7. Transfer curves of $1300{ }^{\circ} \mathrm{C}$ oxidized lateral MOSFET with various conditions.

As mentioned previously, the reliability of the 3C-SiC MOS system is particularly interesting, yet there has been relatively little study of this topic, mainly due to a shortage of non-defective $3 \mathrm{C}$-SiC material. Figure 8 shows the critical strength $\left(E_{c}\right)$ of $\mathrm{SiO}_{2}$ layers grown on $3 \mathrm{C}-\mathrm{SiC} / \mathrm{Si}$ substrates in different atmospheres at $1300{ }^{\circ} \mathrm{C}$. As can be seen, by using combined dry $\mathrm{O}_{2}$ gate oxidation with an $\mathrm{N}_{2} \mathrm{O}$ POA process, the noise level was greatly reduced and the critical electric field strength was able to be kept at around 8 $\mathrm{MV} / \mathrm{cm}$, the highest value observed.
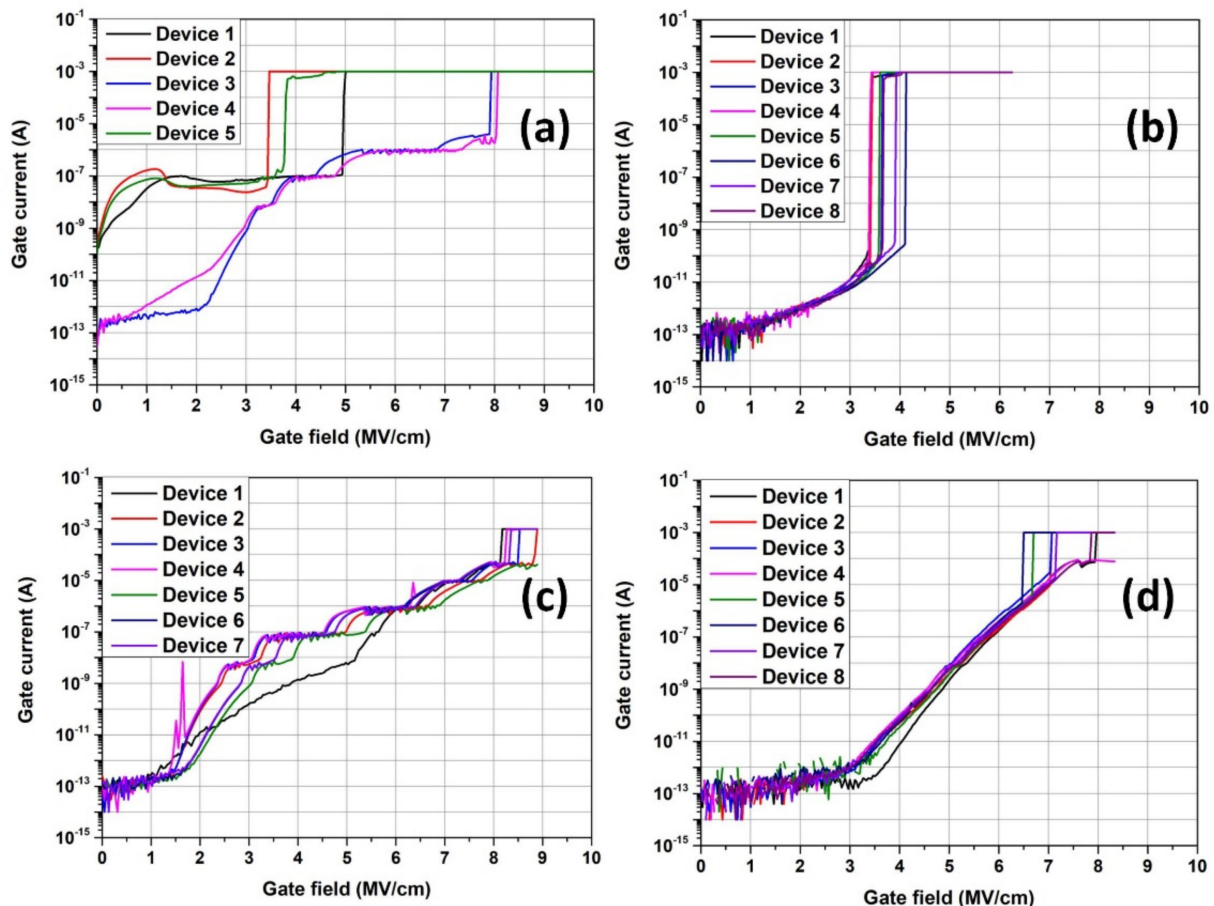

Figure 8. Dielectric breakdown curve of gate oxides fabricated by (a) $60 \mathrm{~min} 1300^{\circ} \mathrm{C}_{2}$ dry oxidation, (b) $15 \mathrm{~min} 1300{ }^{\circ} \mathrm{C} \mathrm{O}_{2}$ wet oxidation, (c) $120 \mathrm{~min} 1300{ }^{\circ} \mathrm{C} \mathrm{N}_{2} \mathrm{O}$ dry oxidation and (d) $30 \mathrm{~min} 1300{ }^{\circ} \mathrm{C}$ $\mathrm{O}_{2}$ dry oxidation $+90 \min 1300{ }^{\circ} \mathrm{C} \mathrm{N}_{2} \mathrm{O}$ POA.

Recently the reliability of 3C-SiC MOS capacitors (dry oxidised and $\mathrm{N}_{2} \mathrm{O}$ POA at $1300^{\circ} \mathrm{C}$ ) has been examined at room temperature by using both $\mathrm{v}$-ramp and time-dependent dielectric breakdown (TDDB) analysis. As can be seen in Figure 9a, the accumulated total failure percentage increases steadily until around $8.5 \mathrm{MV} / \mathrm{cm}$, beyond which the failure 
number sharply increases to $100 \%$. The failures at lower fields are most likely induced by crystal deficiencies in the $3 \mathrm{C}-\mathrm{SiC}$ substrate that alter localised material properties. High field $(>8.5 \mathrm{MV} / \mathrm{cm}$ ) failures are characterized by either F-N tunnelling, observed via the increased leakage current, or electron impact ionization energy being reached within the oxide due to elevated electric fields. TDDB analysis is conducted at electric field values of $6,7.5,8.5$, and $9 \mathrm{MV} / \mathrm{cm}$. The Weibull distributions are displayed in Figure 9b. Even at high fields beyond $8.5 \mathrm{MV} / \mathrm{cm}$, the slope values remain low in the region of $\sim 1$, an order of magnitude lower than reported values for $4 \mathrm{H}-\mathrm{SiC}$ [78], suggesting extrinsic defects are still the dominant failure mechanism.
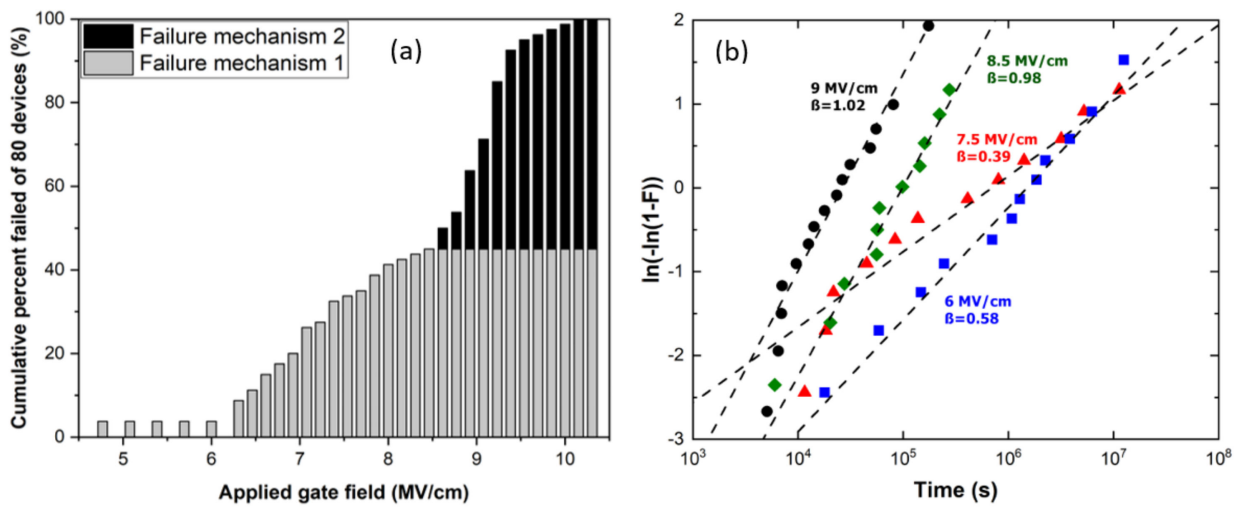

Figure 9. (a) Failure distribution of 3C-SiC MOS capacitors in the electric field range of 4.5-10.5 MV/cm, and (b) Weibull distributions of device failures at various electric fields.

Besides the application on Schottky contacts described in Section 3.1, nanoscale resolution current mapping by C-AFM can also be a powerful analysis technique for investigation of the dielectric breakdown behaviour of thin insulators. In fact, this method was recently employed by Fiorenza et al. [79] in order to explain the reasons behind the premature breakdown of thermal oxide $\left(\mathrm{SiO}_{2}\right)$ grown on 3C-SiC typically observed in MOS capacitors, by stressing the oxide through the application of a bias to the C-AFM tip corresponding to an electric field of $8 \mathrm{MV} / \mathrm{cm}$ (see schematic set-up in Figure 10a).
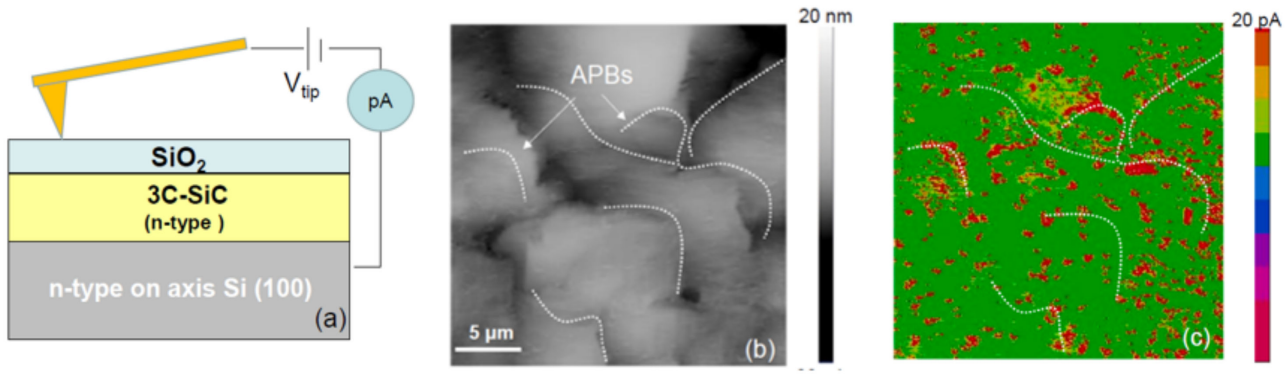

Figure 10. (a) C-AFM set-up adopted for the electrical characterization of the $\mathrm{SiO}_{2} / 3 \mathrm{C}-\mathrm{SiC}$ system; (b) AFM morphology and (c) C-AFM current map acquired under the application of an electric field of $8 \mathrm{MV} / \mathrm{cm}$ to the tip. Adapted with permission from ref. [79]. Copyright (c) 2021 Elsevier Ltd.

The C-AFM current map and corresponding AFM surface morphology acquired on the $\mathrm{SiO}_{2} / \mathrm{SiC}$ system are reported in Figure 10b,c, respectively. The C-AFM current map in Figure 10c reflects the breakdown distribution of an array of tip/oxide nano-MOS capacitors. Hence, the features on the surface morphology (Figure 10b) could be correlated with the position of the breakdown spots (Figure 10c), which are not randomly distributed, but preferentially appear along the APBs (dashed line in Figure 10b). Here, the straight line conductive aspects associated with SFs on the exposed $3 \mathrm{C}-\mathrm{SiC}$ surface (see Figure 10c) were not visible in the presence of a thermal oxide. Based on this analysis, the premature dielectric breakdown observed in MOS capacitors could be attributed to the presence of 
positively charged APBs, causing an electron injection enhancement from the $3 \mathrm{C}-\mathrm{SiC}$ into the $\mathrm{SiO}_{2}$.

Table 5 is a list of recent work performed on the study of 3C-SiC MOS interface traps.

Table 5. A summary of literature data on the processing of 3C-SiC MOS interface and relevant information on fixed charges $\left(Q_{f c}\right)$, interface trap density $\left(D_{i t}\right)$, and oxide critical field $\left(E_{c}\right)$, unless specified, the 3C-SiC materials listed are epilayers.

\begin{tabular}{|c|c|c|c|c|c|c|}
\hline $\begin{array}{l}\text { Oxidation } \\
\text { Substrate }\end{array}$ & Oxidation & POA & $Q_{f c}\left(\mathrm{~cm}^{-2}\right)$ & $\begin{array}{c}D_{i t} \\
\left(\mathrm{~cm}^{-2} \mathrm{eV}^{-1}\right)\end{array}$ & $E_{c}(\mathrm{MV} / \mathrm{cm})$ & Ref. \\
\hline n-type 3C-SiC & $\mathrm{NO}, 1175^{\circ} \mathrm{C}, 4 \mathrm{~h}$ & - & - & $\sim 10^{11}$ & - & {$[68]$} \\
\hline $\begin{array}{l}\text { Al implanted } \\
\text { 3C-SiC }\end{array}$ & $\begin{array}{c}\text { Dry } \mathrm{O}_{2}, 1100^{\circ} \mathrm{C} \\
1.5 \mathrm{~h}\end{array}$ & $\begin{array}{c}\text { Wet } \mathrm{O}_{2}, 950{ }^{\circ} \mathrm{C} \text {, } \\
3 \mathrm{~h}\end{array}$ & - & $5 \times 10^{12}-1 \times 10^{13}$ & - & [74] \\
\hline n-type 3C-SiC & $\begin{array}{c}\text { Dry } \mathrm{O}_{2}, 1120^{\circ} \mathrm{C} \\
0.5 \mathrm{~h}\end{array}$ & $\mathrm{Ar}, 1120^{\circ} \mathrm{C}, 1 \mathrm{~h}$ & - & $\sim 10^{12}$ & - & [75] \\
\hline \multirow{5}{*}{ n-type 3C-SiC } & \multirow{5}{*}{$\begin{array}{c}\operatorname{PECVD}\left(\mathrm{SiH}_{4}+\right. \\
\left.\mathrm{N}_{2} \mathrm{O}\right)\end{array}$} & $\begin{array}{c}\mathrm{N}_{2} \mathrm{O}, 1100^{\circ} \mathrm{C}, 3 \\
\mathrm{~h}\end{array}$ & $2.01 \times 10^{12}$ & $\sim 10^{12}$ & 8.2 & \multirow{5}{*}{ [80] } \\
\hline & & $\begin{array}{c}\text { Wet } \mathrm{O}_{2}, 950{ }^{\circ} \mathrm{C}, \\
3 \mathrm{~h}\end{array}$ & $1.7 \times 10^{11}$ & $\sim 2 \times 10^{12}$ & 9.1 & \\
\hline & & $\begin{array}{c}\text { Dry } \mathrm{O}_{2}, 950{ }^{\circ} \mathrm{C} \\
3 \mathrm{~h}\end{array}$ & $1.76 \times 10^{11}$ & $\sim 2 \times 10^{13}$ & 5.9 & \\
\hline & & $\mathrm{N}_{2}, 1100{ }^{\circ} \mathrm{C}, 3 \mathrm{~h}$ & $4.65 \times 10^{12}$ & $\sim 7 \times 10^{12}$ & 6.3 & \\
\hline & & $\mathrm{N}_{2}, 950^{\circ} \mathrm{C}, 3 \mathrm{~h}$ & $2.63 \times 10^{12}$ & $\sim 2 \times 10^{13}$ & 6.2 & \\
\hline \multirow{2}{*}{ n-type 3C-SiC } & $\mathrm{NO}, 1185^{\circ} \mathrm{C}, 2 \mathrm{~h}$ & - & - & $\sim 10^{12}$ & - & \multirow{2}{*}{ [77] } \\
\hline & $\mathrm{N}_{2} \mathrm{O}, 1185^{\circ} \mathrm{C}, 1 \mathrm{~h}$ & - & - & $\sim 8 \times 10^{11}$ & - & \\
\hline \multirow{7}{*}{ n-type 3C-SiC } & $\begin{array}{c}\text { Dry } \mathrm{O}_{2}, 1100{ }^{\circ} \mathrm{C}, 4 \\
h\end{array}$ & - & $9.3 \times 10^{12}$ & $4.27 \times 10^{13}$ & - & \multirow{7}{*}{ [73] } \\
\hline & $\begin{array}{c}\text { Dry } \mathrm{O}_{2}, 1200{ }^{\circ} \mathrm{C}, 1 \\
h\end{array}$ & - & $7.1 \times 10^{12}$ & $6.59 \times 10^{13}$ & - & \\
\hline & $\begin{array}{c}\text { Dry } \mathrm{O}_{2}, 1100{ }^{\circ} \mathrm{C} \\
1.5 \mathrm{~h}\end{array}$ & $\mathrm{O}_{2}, 950^{\circ} \mathrm{C}, 3 \mathrm{~h}$ & $1.3 \times 10^{12}$ & $7.1 \times 10^{12}$ & - & \\
\hline & $\begin{array}{c}\text { Dry } \mathrm{O}_{2}, 1100^{\circ} \mathrm{C} \\
1.5 \mathrm{~h}\end{array}$ & $\begin{array}{c}\text { Wet } \mathrm{O}_{2}, 950{ }^{\circ} \mathrm{C} \text {, } \\
3 \mathrm{~h}\end{array}$ & $0.9 \times 10^{12}$ & $5.2 \times 10^{12}$ & - & \\
\hline & $\mathrm{N}_{2} \mathrm{O}, 1200^{\circ} \mathrm{C}, 2 \mathrm{~h}$ & \multirow[t]{2}{*}{ - } & $3.0 \times 10^{12}$ & $1.15 \times 10^{13}$ & - & \\
\hline & $\mathrm{N}_{2} \mathrm{O}, 1250^{\circ} \mathrm{C}, 2 \mathrm{~h}$ & & $3.1 \times 10^{12}$ & $9.1 \times 10^{12}$ & - & \\
\hline & $\mathrm{N}_{2} \mathrm{O}, 1250^{\circ} \mathrm{C}, 2 \mathrm{~h}$ & $\begin{array}{c}\text { Wet } \mathrm{O}_{2}, 950{ }^{\circ} \mathrm{C}, \\
3 \mathrm{~h}\end{array}$ & $1.6 \times 10^{12}$ & $9.4 \times 10^{12}$ & - & \\
\hline n-type 3C-SiC & $\begin{array}{c}\operatorname{PECVD}\left(\mathrm{SiH}_{4}+\right. \\
\left.\mathrm{N}_{2} \mathrm{O}\right)\end{array}$ & $\mathrm{N}_{2}, 950{ }^{\circ} \mathrm{C}$ & $5.7-7 \times 10^{12}$ & $5 \times 10^{11}-7 \times 10^{12}$ & - & [81] \\
\hline \multirow{3}{*}{ n-type 3C-SiC } & Dry $\mathrm{O}_{2}, 1200^{\circ} \mathrm{C}$ & \multirow{3}{*}{ - } & $1.1 \times 10^{12}$ & \multirow{3}{*}{$\sim 10^{12}$} & \multirow{3}{*}{ - } & \multirow{3}{*}{ [82] } \\
\hline & Dry $\mathrm{O}_{2}, 1300^{\circ} \mathrm{C}$ & & $1.1 \times 10^{12}$ & & & \\
\hline & Dry $\mathrm{O}_{2}, 1400^{\circ} \mathrm{C}$ & & $4.1 \times 10^{12}$ & & & \\
\hline
\end{tabular}

\section{3C-SiC Device Prototypes}

\subsection{Schottky Diode}

The study of Schottky and p-n junction diode behaviour on thin film CVD 3C-SiC dates back to the 1980s [83]. Much of this early work was conducted on thin films deposited on silicon and $6 \mathrm{H}-\mathrm{SiC}$. The initial studies were concerned with the surface science of fabricating appropriate metal contacts. These diodes demonstrated the first reported 3C$\mathrm{SiC}$ rectification behaviour of up to $200 \mathrm{~V}$, with leakage currents ranging from between $10^{-4}-1 \mathrm{~A} / \mathrm{cm}^{2}[84,85]$. Vertical heterojunction Schottky diodes based on platinum $(\mathrm{Pt})$ 
contacts showed a blocking voltage of $85 \mathrm{~V}$ with a low forward voltage drop of $\sim 0.85 \mathrm{~V}$ [86]. Gold contacts to $3 \mathrm{C}-\mathrm{SiC}$ for Schottky diode applications displayed a variance of the barrier height with contact area [19]. This can be explained by the defect density inherent within the starting material. More recent Schottky diode reports suggest that the leakage current is not dominated by SF density, as the leakage current had a greater dependency on the barrier height [87]. Barrier height nonuniformities of the Schottky barrier have been observed on lateral 3C-SiC-on-Si diodes, implicating complex trapping/de-trapping phenomena observed within the material [88]. The information acquired has led to validated technology computer aided design (TCAD) models for accurate 3C-SiC device simulation [9].

\subsection{PiN Diode}

Attributed to its smaller bandgap, 3C-SiC has a lower p-n junction built-in potential $(\approx 1.75 \mathrm{~V})$ than $4 \mathrm{H}-\mathrm{SiC}(\approx 3 \mathrm{~V})$. In [9] it is shown that, up to $4.5 \mathrm{kV}$ blocking voltage, the forward voltage drop at $250 \mathrm{~A} / \mathrm{cm}^{2}$ remains lower for $3 \mathrm{C}-\mathrm{SiC}$ than $4 \mathrm{H}-\mathrm{SiC}$ in PiN diode applications. Until recently, however, fabricating 3C-SiC PiN diodes has been difficult, not only because of the high defect density within 3C-SiC epilayers caused by the lattice mismatch with $\mathrm{Si}$ [21], but also due to the lateral nature of structures necessary to avoid the $3 \mathrm{C}-\mathrm{SiC} / \mathrm{Si}$ heterojunction. While there are several reports on achieving $\mathrm{n}$ type conduction in 3C-SiC epi/implanted layers $[42,48,66]$, and p-type conduction in $\mathrm{Al}$ doped epilayers $[66,89]$, it remains an obstacle for p-type implanted layers. This is mainly due to the post implantation anneal temperature, which was limited to the Si melting point, $1414{ }^{\circ} \mathrm{C}$, which is not sufficient to activate the deep level $\mathrm{Al}$ dopants, even if hot implantation was applied.

Low voltage lateral p-n junction diodes were previously demonstrated via the formation of implanted $\mathrm{n}+$ regions in p-type doped 3C-SiC epilayers grown on $\mathrm{Si}$ substrates $[90,91]$. However, to make the most of its benefits in power applications, a vertical structure is necessary. 3C-SiC growth methods have improved in recent years [6,92,93], and bulk $3 \mathrm{C}-\mathrm{SiC}$ are now available [51]; thus, a higher annealing temperature can now be applied. Vertical PiN diodes were fabricated on free standing 3C-SiC material by implanting $\mathrm{Al}$ in n-type doped epilayer and the forward current density is shown in Figure 11a. The built-in potential of the fabricated PiN diode is around $2 \mathrm{~V}$, slightly higher than the theoretical value $1.75 \mathrm{~V}$ [9], but it is still much lower than the typical $>3 \mathrm{~V}$ for $4 \mathrm{H}-\mathrm{SiC}$ [94-96]. The forward current density goes above $1000 \mathrm{~A} / \mathrm{cm}^{2}$ at $2.7 \mathrm{~V}$, and the lowest differential resistance is estimated to be $0.5 \mathrm{~m} \Omega \mathrm{cm}^{2}$. The device on-off ratio at $\pm 5 \mathrm{~V}$ is as high as $10^{9}$, as shown in Figure 11b, and a blocking voltage above $100 \mathrm{~V}$ is achieved (Figure 11c). An observation to note with respect to bipolar PiN diode I-V characterisation is that no bipolar degradation has been reported in the literature with respect to $3 \mathrm{C}-\mathrm{SiC}$ pn diodes. This is most likely due to the fact that attention is being placed upon more fundamental device limiting issues such as SF-induced leakage currents.
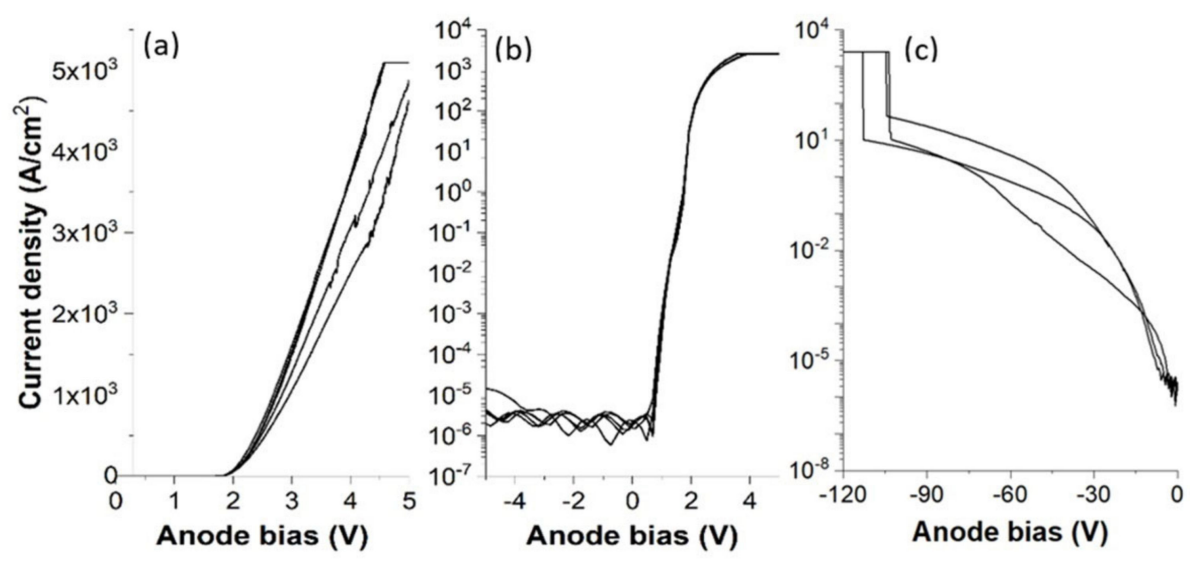

Figure 11. (a) Forward J-V characteristics, (b) on-off performance at $\pm 5 \mathrm{~V}$, and (c) reverse breakdown of bulk 3C-SiC PiN diodes. 


\subsection{MOSFET}

Early 3C-SiC power devices were predominantly demonstrated via heteroepitaxial 3C-SiC grown by chemical vapour deposition (CVD) above silicon substrates in addition to free-standing wafers, provided by HOYA Advanced Semiconductor Technologies Co Ltd. $[50,74,97,98]$. Power devices were based on diode and MOSFET (lateral and vertical) architectures. Devices demonstrated by 3C-SiC CVD grown on undulant-silicon substrates suffered from premature breakdown voltage and high leakage currents due to APBs and SF inherent within the epitaxial layer of the device $[99,100]$.

Typical characteristics showed that achieving breakdown voltages in excess of $600 \mathrm{~V}$ was challenging since the leakage current emanating from the formerly mentioned $p-n$ junction SFs degraded performance in a terminal manner [100]. High current cellular vertical 3C-SiC MOSFETs were demonstrated by Abe et al. [74]. This device achieved an impressive $1220 \mathrm{~A} / \mathrm{cm}^{2}$ current density based on a single cell. This corresponds to a current carrying capability of 41-132 A for a $3 \times 3 \mathrm{~mm}^{2}, 600 \mathrm{~V}$ chip. SF-induced leakage current hampered the off-state performance of this MOSFET. CVD deposited gates produced 600 V-MOSFETs with a high channel mobility of $200 \mathrm{~cm}^{2} /$ Vs [101]. The high channel mobility and low specific on-state resistance of $5-7 \mathrm{~m} \Omega \mathrm{cm}^{2}$ were brought about by a specific activation anneal of $1600{ }^{\circ} \mathrm{C}$ in argon (Ar), in order to realise a smooth $3 \mathrm{C}$-SiC surface prior to deposition of the gate oxide. They used $600 \mathrm{~V}$ DMOSFETs to show that material quality has a strong influence on the blocking behaviour. In contrast, the on-state electrical characteristics were unaffected [102]. A 200V reduction in breakdown voltage was observed for DMOSFETs with a high crystal defect density.

Due to the lower interface trap density at the $3 \mathrm{C}-\mathrm{SiC} / \mathrm{SiO}_{2}$ interface compared with $4 \mathrm{H}-\mathrm{SiC}, \mathrm{MOSFETs}$ are the most studied 3C-SiC devices, targeting for lower on-resistance than $4 \mathrm{H}-\mathrm{SiC}$ MOSFETs in medium voltage applications (600-1200V). High field-effect mobility values were demonstrated by fabricating $3 \mathrm{C}-\mathrm{SiC}$ MOSFETs with a high current density of $1220 \mathrm{~A} / \mathrm{cm}^{2}$ and encouraging scaling features were shown in $1 \mathrm{~mm} \times 1 \mathrm{~mm}$ and $3 \mathrm{~mm} \times 3 \mathrm{~mm}$ devices [74]. In addition, it is shown in $[65,68]$ that by removing the rapid thermal anneal for the ohmic contact, the field-effect mobility can be further improved. Despite the achievements made in forward conditions, reaching blocking ability (BV) close to the theoretical values is still a challenge, mainly because of the high leakage current induced by crystal defects such as SFs [97]. By reducing stacking faults to $\sim 90 \mathrm{~cm}^{-1}$, the device blocking ability $\left(5 \times 10^{15} \mathrm{~cm}^{-3}\right.$ doped drift region) can be significantly improved to $600 \mathrm{~V}$ [50], close to the unipolar limit. Table 6 is a summary of the recent literature results for 3C-SiC MOSFET fabrication.

Table 6. A summary of literature data on the forward and reverse performance of 3C-SiC MOSFETs.

\begin{tabular}{|c|c|c|c|c|c|c|}
\hline Structure & Channel & Oxidation & POA & $\mu_{F E}\left(\mathrm{~cm}^{2} / \mathrm{V} . \mathrm{s}\right)$ & $B_{V}(\mathrm{~V})$ & Ref. \\
\hline Lateral & $\begin{array}{c}2 \times 10^{17} \mathrm{~cm}^{-3} \\
\text { p-type epi }\end{array}$ & $\begin{array}{c}\text { Wet } \mathrm{O}_{2}, 1150^{\circ} \mathrm{C}, \\
2.5 \mathrm{~h}\end{array}$ & $\begin{array}{l}\text { Ar, } 1150{ }^{\circ} \mathrm{C}, 0.5 \mathrm{~h}+ \\
\text { Wet } \mathrm{O}_{2}, 950^{\circ} \mathrm{C}, 2 \mathrm{~h}\end{array}$ & $\approx 165$ & - & [73] \\
\hline Lateral & $\begin{array}{c}1 \times 10^{16} \mathrm{~cm}^{-3} \\
\text { p-type epi }\end{array}$ & Wet $\mathrm{O}_{2}, 1100^{\circ} \mathrm{C}$ & $\begin{array}{c}\text { Ar, } 1150{ }^{\circ} \mathrm{C}, 0.5 \mathrm{~h}+ \\
\text { Wet } \mathrm{O}_{2}, 800^{\circ} \mathrm{C}, 0.5 \mathrm{~h}\end{array}$ & $\approx 229$ & - & [103] \\
\hline Lateral & $\begin{array}{l}1 \times 10^{18} \mathrm{~cm}^{-3} \\
\mathrm{Al} \text { implanted }\end{array}$ & Dry $\mathrm{O}_{2}, 1300{ }^{\circ} \mathrm{C}$ & - & $\approx 80$ & - & [65] \\
\hline Vertical & $\begin{array}{l}1 \times 10^{18} \mathrm{~cm}^{-3} \\
\mathrm{Al} \text { implanted }\end{array}$ & $\begin{array}{c}\text { Dry } \mathrm{O}_{2}, 1100^{\circ} \mathrm{C}, \\
1.5 \mathrm{~h}\end{array}$ & Wet $\mathrm{O}_{2}, 950{ }^{\circ} \mathrm{C}, 3 \mathrm{~h}$ & $\approx 28$ & $\approx 100$ & [68] \\
\hline Vertical & $\begin{array}{l}1 \times 10^{18} \mathrm{~cm}^{-3} \\
\mathrm{Al} \text { implanted }\end{array}$ & $\begin{array}{c}\text { Dry } \mathrm{O}_{2}, 1100^{\circ} \mathrm{C}, \\
1.5 \mathrm{~h}\end{array}$ & Wet $\mathrm{O}_{2}, 950^{\circ} \mathrm{C}, 3 \mathrm{~h}$ & $\approx 45$ & $550-600$ & [50] \\
\hline Vertical & Al implanted & Wet $\mathrm{O}_{2}, 1150{ }^{\circ} \mathrm{C}$, & - & $>100$ & & [104] \\
\hline
\end{tabular}




\section{Conclusions}

This paper gave an overview of the processing technology associated with heteroepitaxial 3C-SiC-on-silicon, including the more recently available bulk 3C-SiC studies. This topic is highly relevant today since this material presents some clear advantages over its commercial WBG competitors in terms of MOS channel resistance and reliability. These factors are of the utmost importance when considering that it is the automotive sector that is driving the widespread uptake of WBG technologies. Schottky contact processing on 3C-SiC has mainly been conducted on heteroepitaxy (on-silicon) utilising high work function metals such as Au or Pt. These rectifying contacts are typically characterised by high leakage currents arising from SFs and APBs and it is clear that a step-change in material quality is needed for power device applications. To the best of the authors' knowledge, there remains no semiconductor device grade wafer supplier of bulk 3C-SiC. However, heteroepitaxial 3C-SiC-on-silicon is available up to a wafer diameter of 4 inch. The main obstacle to large diameter $3 \mathrm{C}-\mathrm{SiC}$ commercialisation remains the $\mathrm{SF}$ density that ranges from $200-5000 \mathrm{~cm}^{-1}$. Hence, the future prospects for 3C-SiC are incumbent upon reducing $\mathrm{SFs}$ and $\mathrm{APBs}$, which remains key to realising large diameter $3 \mathrm{C}-\mathrm{SiC}$ bulk wafer production. 3C-SiC-on-silicon demonstrates serious limitations when the ion implantation process is taken into consideration. Therefore, the majority of studies to date have used conventional PIA annealing up to $1400{ }^{\circ} \mathrm{C}$ (melting temperature of silicon substrate) and pulsed laser annealing. Generally, dopant activation rates are low in 3C-SiC heteroepitaxy structures, although recently more promising behaviour has been described on free standing (bulk) 3C-SiC. Most recently p-type aluminium doped 3C-SiC has been demonstrated with weak p-type behaviour. N-type ohmic contacts have been consistently achieved using metals such as $\mathrm{Ni}, \mathrm{Al}, \mathrm{Ti}, \mathrm{Au}$ and $\mathrm{W}$ demonstrating specific contact resistivities as low as $5 \times 10^{-7} \Omega \mathrm{cm}^{2}$. The success is related to the high n-type ion implantation activation/ionisation rates accompanied by the low donor levels relative to $4 \mathrm{H}-\mathrm{SiC}$. P-type ohmicity based on metals including $\mathrm{Al}, \mathrm{Ni}$, Ti and poly-silicon have produced resistances in the region of $\sim 10^{-5} \Omega \mathrm{cm}^{2}$. Compared to n-type donor levels in 3C-SiC, p-type acceptor energy levels are closer to the midgap, resulting in a lower degree of acceptor ionization. Diodes based on Schottky and PiN designs have been demonstrated on 3C-SiC. The state of the art with respect to diodes are bulk PiN structures with a built-in voltage of $2 \mathrm{~V}$ and current density of $1000 \mathrm{Acm}^{-2}$ observed. The 3C-SiC MOS interface is relatively untroubled by near interface traps when compared to its $4 \mathrm{H}-\mathrm{SiC}$ counterpart. This can be inferred from experimental results based on nitrogen anneals where channel mobilities approaching $100 \mathrm{~cm}^{2} / \mathrm{Vs}$ have been observed. Again nitrogen-based thermal oxidation produced interface trap densities in the region of $10^{11} \mathrm{~cm}^{-2} \mathrm{eV}^{-1}$. A reliability analysis of the 3C-SiC MOS interface revealed high breakdown fields in the region of $8 \mathrm{MV} / \mathrm{cm}$ including cumulative device failure arising primarily from 3C-SiC crystal defects (TDDB). Actual MOSFET demonstrators are plagued by high leakage currents resulting from crystal defects. Thus, 600V 3C-SiC MOSFETs that approach the theoretical unipolar limit have been demonstrated.

Author Contributions: Conceptualization, writing, review and editing, F.L., M.J., F.R.; experimental investigation, F.L., M.J., F.R., G.G., P.F.; data analysis and discussion, J.E.E., F.A.M., F.L., C.A.F., A.P.-T., P.A.M., P.F., M.J., F.R.; funding acquisition, F.L.V. All authors have read and agreed to the published version of the manuscript.

Funding: This research was funded by the European Union within the framework of the project CHALLENGE, grant number 720827.

Institutional Review Board Statement: Not applicable.

Informed Consent Statement: Not applicable.

Data Availability Statement: The data underlying this article will be shared on reasonable request from the corresponding author.

Conflicts of Interest: The authors declare no conflict of interest. 


\section{References}

1. Roccaforte, F.; Greco, G.; Fiorenza, P.; Iucolano, F. An Overview of Normally-Off GaN-Based High Electron Mobility Transistors. Materials 2019, 12, 1599. [CrossRef] [PubMed]

2. Tolbert, L.M.; King, T.; Ozpineci, B.; Campbell, J.; Muralidharan, G.; Rizy, D.; Sabau, A.; Zhang, H.; Zhang, W.; Xu, Y.; et al. Power Electronics for Distributed Energy Systems and Transmission and Distribution Applications: Assessing the Technical Needs for Utility Applications; U.S. Department of Energy Office of Scientific and Technical Information: Washington, DC, USA, 2005. [CrossRef]

3. Yole Development. From Technologies to Markets: Compound Semiconductor Service Compound Montior; Quarterly Update-Q1 2020; Yole Development: Lyon, France, 2020.

4. Ueda, T. Reliability Issues in GaN and SiC Power Devices. IEEE Int. Reliab. Phys. Symp. Proc. 2014, 1-6. [CrossRef]

5. Gonzalez, J.O.; Wu, R.; Jahdi, S.; Alatise, O. Performance and Reliability Review of $650 \mathrm{v}$ and $900 \mathrm{v}$ Silicon and SiC Devices: MOSFETs, Cascode JFETs and IGBTs. IEEE Trans. Ind. Electron. 2020, 67, 7375-7385. [CrossRef]

6. Chow, T.P.; Omura, I.; Higashiwaki, M.; Kawarada, H.; Pala, V. Smart Power Devices and ICs Using GaAs and Wide and Extreme Bandgap Semiconductors. IEEE Trans. Electron Devices 2017, 64, 856-873. [CrossRef]

7. La Via, F.; Severino, A.; Anzalone, R.; Bongiorno, C.; Litrico, G.; Mauceri, M.; Schoeler, M.; Schuh, P.; Wellmann, P. From Thin Film to Bulk 3C-SiC Growth: Understanding the Mechanism of Defects Reduction. Mater. Sci. Semicond. Process. 2018, 78, 57-68. [CrossRef]

8. Levinshein, M.; Sergey, L.; Shur, M. (Eds.) Properties of Advanced Semiconductor Materials: GaN, AIN, InN, BN, SiC, SiGe, 1st ed.; John Wiley \& Sons, Inc.: New York, NY, USA, 2001.

9. Lebedev, A.; Lebedev, S.; Dayvdov, V.; Novikov, S.; Makarov, Y. Growth and Investigation of SiC Based Herterostructures. In Proceedings of the 2016 15th Biennial Baltic Electronics Conference (BEC), Tallinn, Estonia, 3-5 October 2016; pp. 4-5.

10. Arvanitopoulos, A.E.; Antoniou, M.; Perkins, S.; Jennings, M.; Guadas, M.B.; Gyftakis, K.N.; Lophitis, N. On the Suitability of 3C-Silicon Carbide as an Alternative to 4H-Silicon Carbide for Power Diodes. IEEE Trans. Ind. Appl. 2019, 55, 4080-4090. [CrossRef]

11. Silicon Carbide Properties. Available online: https://www.ece.rutgers.edu/ \{\}jzhao/SiC-properties.html (accessed on 20 May 2021).

12. Bimberg, D.; Altarelli, M.; Lipari, N.O. A Calculation of Valence Band Masses, Exciton and Acceptor Energies and the Ground State Properties of the Electron-Hole Liquid in Cubic SiC. Solid State Commun. 1981, 40, 437-440. [CrossRef]

13. Fardi, H.; Van Zeghbroeck, B. Design and Simulation of 3C-SiC Vertical Power MOSFETs. Int. J. Electron. 2021, 108, 841-857. [CrossRef]

14. Salupo, C.S.; Larkin, D.J.; Powell, J.A.; Matus, L.G. Electrical Properties of Epitaxial 3C-and 6H-SiC p-n Junction Diodes Produced Side-by-Side on 6H-SiC Substrates. IEEE Trans. Electron Devices 1994, 41, 826-835. [CrossRef]

15. Spry, D.J.; Trunek, A.J.; Neudeck, P.G. High Breakdown Field P-Type 3C-SiC Schottky Diodes Grown on Step-Free 4H-SiC Mesas. In Silicon Carbide and Related Materials 2003; Materials Science Forum; Trans Tech Publications Ltd.: Bäch, Switzerland, 2004; Volume 457, pp. 1061-1064. [CrossRef]

16. Tirino, L.; Weber, M.; Brennan, K.F.; Bellotti, E.; Goano, M. Temperature Dependence of the Impact Ionization Coefficients in GaAs, Cubic SiC, and Zinc-Blende GaN. J. Appl. Phys. 2003, 94, 423-430. [CrossRef]

17. Bellotti, E.; Nilsson, H.-E.; Brennan, K.F.; Ruden, P.P. Ensemble Monte Carlo Calculation of Hole Transport in Bulk 3C-SiC. J. Appl. Phys. 1999, 85, 3211-3217. [CrossRef]

18. Fardi, H.; Van Zeghbroeck, B. Breakdown Field Model for 3C-SiC Power Device Simulations. Mater. Sci. Forum 2018, 924, 617-620. [CrossRef]

19. Eriksson, J.; Weng, M.H.; Roccaforte, F.; Giannazzo, F.; Leone, S.; Raineri, V. Toward an Ideal Schottky Barrier on 3C-SiC. Appl. Phys. Lett. 2009, 95, 81907. [CrossRef]

20. Lanzia, M. (Ed.) Conductive Atomic Force Microscopy: Applications in Nanomaterials; Wiley VCH: Weinheim, Germany, 2017.

21. Giannazzo, F.; Greco, G.; Di Franco, S.; Fiorenza, P.; Deretzis, I.; La Magna, A.; Bongiorno, C.; Zimbone, M.; La Via, F.; Zielinski, M.; et al. Impact of Stacking Faults and Domain Boundaries on the Electronic Transport in Cubic Silicon Carbide Probed by Conductive Atomic Force Microscopy. Adv. Electron. Mater. 2020, 6, 1-8. [CrossRef]

22. Yoshida, S.; Sasaki, K.; Sakuma, E.; Misawa, S.; Gonda, S. Schottky Barrier Diodes on 3C-SiC. Appl. Phys. Lett. 1985, 46, 766-768. [CrossRef]

23. Ioannou, D.E.; Papanicolaou, N.A.; Nordquist, P.E. The Effect of Heat Treatment on Au Schottky Contacts on $\beta$-SiC. IEEE Trans. Electron Devices 1987, 34, 1694-1699. [CrossRef]

24. Fujii, Y.; Shigeta, M.; Furukawa, K.; Suzuki, A.; Nakajima, S. Dependence on the Schottky Metal and Crystal Orientation of the Schottky Diode Characteristics of B-SiC Single Crystals Grown by Chemical Vapor Deposition. J. Appl. Phys. 1988, 64, 5020-5025. [CrossRef]

25. Papanicolaou, N.A.; Christou, A.; Gipe, M.L. Pt and PtSix Schottky Contacts on N-type B-SiC. J. Appl. Phys. 1989, 65, 3526-3530. [CrossRef]

26. Waldrop, J.R.; Grant, R.W. Formation and Schottky Barrier Height of Metal Contacts to B-SiC. Appl. Phys. Lett. 1990, 56, 557-559. [CrossRef]

27. Constantinidis, G.; Kuzmic, J.; Michelakis, K.; Tsagaraki, K. Schottky Contacts on CF4/H2 Reactive Ion Etched $\beta$-SiC. Solid State Electron. 1998, 42, 253-256. [CrossRef] 
28. Roy, S.; Jacob, C.; Basu, S. Current Transport Properties of Pd/3C-SiC Schottky Junctions with Planar and Vertical Structures. Solid State Sci. 2004, 6, 377-382. [CrossRef]

29. Satoh, M.; Matsuo, H. Evaluation of Schottky Barrier Height of Al, Ti, Au, and Ni Contacts to 3C-SiC. Mater. Sci. Forum 2006, 527, 923-926. [CrossRef]

30. Eriksson, J.; Roccaforte, F.; Reshanov, S.; Giannazzo, F.; Lo Nigro, R.; Raineri, V. Evolution of the Electrical Characteristics of $\mathrm{Pt} / 3 \mathrm{C}-\mathrm{SiC}$ Schottky Contacts upon Thermal Annealing. AIP Conf. Proc. 2010, 1292, 75-78. [CrossRef]

31. Alassaad, K.; Vivona, M.; Soulière, V.; Doisneau, B.; Cauwet, F.; Chaussende, D.; Giannazzo, F.; Roccaforte, F.; Ferro, G. Ge Mediated Surface Preparation for Twin Free 3C-SiC Nucleation and Growth on Low Off-Axis 4H-SiC Substrate. ECS J. Solid State Sci. Technol. 2014, 3, P285-P292. [CrossRef]

32. Zhe, F. Silicon Carbide: Materials, Processing \& Devices, 1st ed.; CRC Press: Boca Raton, FL, USA, 2003.

33. Li, M.; Ahyi, A.C.; Zhu, X.; Chen, Z.; Isaacs-Smith, T.; Williams, J.R.; Crofton, J. Nickel Ohmic Contacts to N-Implanted (0001) 4H-SiC. J. Electron. Mater. 2010, 39, 540-544. [CrossRef]

34. Vivona, M.; Greco, G.; Giannazzo, F.; Lo Nigro, R.; Rascunà, S.; Saggio, M.; Roccaforte, F. Thermal Stability of the Current Transport Mechanisms in Ni-Based Ohmic Contacts on n- and p-Implanted 4H-SiC. Semicond. Sci. Technol. 2014, $29,75018$. [CrossRef]

35. Jones, K.A.; Wood, M.C.; Zheleva, T.S.; Kirchner, K.W.; Derenge, M.A.; Bolonikov, A.; Sudarshan, T.S.; Vispute, R.D.; Hullavarad, S.S.; Dhar, S. Structural and Chemical Comparison of Graphite and BN/AIN Caps Used for Annealing Ion Implanted SiC. J. Electron. Mater. 2008, 37, 917-924. [CrossRef]

36. Frazzetto, A.; Giannazzo, F.; Nigro, R.L.; Raineri, V.; Roccaforte, F. Structural and Transport Properties in Alloyed Ti/Al Ohmic Contacts Formed on p-Type Al-Implanted 4H-SiC Annealed at High Temperature. J. Phys. D Appl. Phys. 2011, $44,255302$. [CrossRef]

37. Jacob, C.; Pirouz, P.; Kuo, H.-I.; Mehregany, M. High Temperature Ohmic Contacts to 3C-Silicon Carbide Films. Solid State Electron. 1998, 42, 2329-2334. [CrossRef]

38. Nipoti, R.; Canino, M.; Zielinski, M.; Torregrosa, F.; Carnera, A. $1300{ }^{\circ} \mathrm{C}$ Annealing of $1 \times 1020^{\circ} \mathrm{C} \mathrm{m}{ }^{-3} \mathrm{Al}+$ Ion Implanted 3C-SiC/Si. ECS J. Solid State Sci. Technol. 2019, 8, P480-P487. [CrossRef]

39. Capano, M.A.; Ryu, S.; Cooper, J.A.; Melloch, M.R.; Rottner, K.; Karlsson, S.; Nordell, N.; Powell, A.; Walker, D.E. Surface Roughening in Ion Implanted 4H-Silicon Carbide. J. Electron. Mater. 1999, 28, 214-218. [CrossRef]

40. Negoro, Y.; Katsumoto, K.; Kimoto, T.; Matsunami, H. Electronic Behaviors of High-Dose Phosphorus-Ion Implanted 4H-SiC (0001). J. Appl. Phys. 2004, 96, 224-228. [CrossRef]

41. Vassilevski, K.V.; Wright, N.G.; Nikitina, I.P.; Horsfall, A.B.; O’Neill, A.G.; Uren, M.J.; Hilton, K.P.; Masterton, A.G.; Hydes, A.J.; Johnson, C.M. Protection of Selectively Implanted and Patterned Silicon Carbide Surfaces with Graphite Capping Layer during Post-Implantation Annealing. Semicond. Sci. Technol. 2005, 20, 271-278. [CrossRef]

42. Song, X.; Biscarrat, J.; Michaud, J.-F.; Cayrel, F.; Zielinski, M.; Chassagne, T.; Portail, M.; Collard, E.; Alquier, D. Structural and Electrical Characterizations of N-Type Implanted Layers and Ohmic Contacts on 3C-SiC. Nucl. Instrum. Methods Phys. Res. Sect. B Beam Interact. Mater. Atoms 2011, 269, 2020-2025. [CrossRef]

43. Bazin, A.E.; Michaud, J.F.; Autret-Lambert, C.; Cayrel, F.; Chassagne, T.; Portail, M.; Zielinski, M.; Collard, E.; Alquier, D. Ti-Ni Ohmic Contacts on 3C-SiC Doped by Nitrogen or Phosphorus Implantation. Mater. Sci. Eng. B 2010, 171, 120-126. [CrossRef]

44. Song, X.; Bazin, A.E.; Michaud, J.F.; Cayrel, F.; Zielinski, M.; Portail, M.; Chassagne, T.; Collard, E.; Alquier, D. Electrical Characterization of Nitrogen Implanted 3C-SiC by SSRM and C TLM Measurements. Mater. Sci. Forum 2011, 679, 193-196. [CrossRef]

45. Lee, K.Y.; Huang, Y.H.; Huang, C.F.; Chung, C.Y.; Lin, S.C.; Zhao, F. XRD Characterization for Al- and N-Doped 3C-SiC on Si (100) Substrate after Pulsed Excimer Laser Anneal. Mater. Sci. Forum 2012, 717, 497-500. [CrossRef]

46. Taguchi, E.; Suzuki, Y.; Satoh, M. Electrical Properties of N Ion Implanted Layer in 3C-SiC(100) Grown on Self-Standing 3C-SiC Substrate. Mater. Sci. Forum 2007, 556, 579-582. [CrossRef]

47. Khemka, V.; Patel, R.; Ramungul, N.; Chow, T.P.; Ghezzo, M.; Kretchmer, J. Characterization of Phosphorus Implantation in 4H-SiC. J. Electron. Mater. 1999, 28, 167-174. [CrossRef]

48. Li, F.; Sharma, Y.; Shah, V.; Jennings, M.; Pérez-Tomás, A.; Myronov, M.; Fisher, C.; Leadley, D.; Mawby, P. Electrical Activation of Nitrogen Heavily Implanted 3C-SiC(100). Appl. Surf. Sci. 2015, 353, 958-963. [CrossRef]

49. Rao, M.V.; Griffiths, P.; Holland, O.W.; Kelner, G.; Freitas, J.A.; Simons, D.S.; Chi, P.H.; Ghezzo, M. Al and B Ion-implantations in 6H- and 3C-SiC. J. Appl. Phys. 1995, 77, 2479-2485. [CrossRef]

50. Nagasawa, H.; Abe, M.; Yagi, K.; Kawahara, T.; Hatta, N. Fabrication of High Performance 3C-SiC Vertical MOSFETs by Reducing Planar Defects. Phys. Status Solidi Basic Res. 2008, 245, 1272-1280. [CrossRef]

51. La Via, F.; Mauceri, M.; Scuderi, V.; Calabretta, C.; Zimbone, M.; Anzalone, R. 3C-SiC Bulk Growth: Effect of Growth Rate and Doping on Defects and Stress. Mater. Sci. Forum 2020, 1004, 120-125. [CrossRef]

52. Lossy, R.; Reichert, W.; Obermeier, E. Characterization of 3C-SiC Doped by Nitrogen Implantation. Mater. Sci. Eng. B 1997, 46, 156-159. [CrossRef]

53. Lossy, R.; Reichert, W.; Obermeier, E.; Skorupa, W. Doping of 3C-SiC by Implantation of Nitrogen at High Temperatures. J. Electron. Mater. 1997, 26, 123-127. [CrossRef] 
54. Suzuki, Y.; Taguchi, E.; Nagata, S.; Satoh, M. Evaluation of Specific Contact Resistance of Al, Ti, and Ni Contacts to N Ion Implanted 3C-SiC(100). Mater. Sci. Forum 2007, 556, 705-708. [CrossRef]

55. Song, X.; Biscarrat, J.; Bazin, A.E.; Michaud, J.F.; Cayrel, F.; Zielinski, M.; Chassagne, T.; Portail, M.; Collard, E.; Alquier, D. Dose Influence on Physical and Electrical Properties of Nitrogen Implantation in 3C-SiC on Si. Mater. Sci. Forum 2012, 711, 154-158. [CrossRef]

56. Jennings, M.R.; Fisher, C.A.; Walker, D.; Sanchez, A.; Pérez-Tomás, A.; Hamilton, D.P.; Gammon, P.M.; Burrows, S.E.; Thomas, S.M.; Sharma, Y.K.; et al. On the Ti3SiC2 Metallic Phase Formation for Robust P-Type 4H-SiC Ohmic Contacts. Mater. Sci. Forum 2014, 778, 693-696. [CrossRef]

57. Eriksson, J.; Roccaforte, F.; Giannazzo, F.; Lo Nigro, R.; Raineri, V.; Lorenzzi, J.; Ferro, G. Improved Ni/3C-SiC Contacts by Effective Contact Area and Conductivity Increases at the Nanoscale. Appl. Phys. Lett. 2009, 94, 112104. [CrossRef]

58. Noh, J.I.; Nahm, K.S.; Kim, K.C.; Capano, M.A. Effect of Surface Preparation on Ni Ohmic Contact to 3C-SiC. Solid State Electron. 2002, 46, 2273-2279. [CrossRef]

59. Moki, A.; Shenoy, P.; Alok, D.; Baliga, B.J.; Wongchotigul, K.; Spencer, M.G. Low Resistivity As-Deposited Ohmic Contacts to 3C-SiC. J. Electron. Mater. 1995, 24, 315-318. [CrossRef]

60. Roy, S.; Jacob, C.; Basu, S. Ohmic Contacts to 3C-SiC for Schottky Diode Gas Sensors. Solid State Electron. 2003, 47, $2035-2041$. [CrossRef]

61. Bazin, A.E.; Michaud, J.F.; Cayrel, F.; Portail, M.; Chassagne, T.; Zielinski, M.; Collard, E.; Alquier, D. High Quality Ohmic Contacts on N-type 3C-SiC Obtained by High and Low Process Temperature. AIP Conf. Proc. 2010, 1292, 51-54. [CrossRef]

62. Wan, J.; Capano, M.A.; Melloch, M.R. Formation of Low Resistivity Ohmic Contacts to N-Type 3C-SiC. Solid State Electron. 2002, 46, 1227-1230. [CrossRef]

63. Zhang, J.; Howe, R.T.; Maboudian, R. Nickel and Platinum Ohmic Contacts to Polycrystalline 3C-Silicon Carbide. Mater. Sci. Eng. B 2007, 139, 235-239. [CrossRef]

64. Chung, G.-S.; Yoon, K.-H. Ohmic Contacts to Single-Crystalline 3C-SiC Films for Extreme-Environment MEMS Applications. Microelectron. J. 2008, 39, 1408-1412. [CrossRef]

65. Li, F.; Sharma, Y.; Walker, D.; Hindmarsh, S.; Jennings, M.; Martin, D.; Fisher, C.; Gammon, P.; Pérez-Tomás, A.; Mawby, P. 3C-SiC Transistor with Ohmic Contacts Defined at Room Temperature. IEEE Electron Device Lett. 2016, 37, 1189-1192. [CrossRef]

66. Spera, M.; Greco, G.; Lo Nigro, R.; Bongiorno, C.; Giannazzo, F.; Zielinski, M.; La Via, F.; Roccaforte, F. Ohmic Contacts on N-Type and p-Type Cubic Silicon Carbide (3C-SiC) Grown on Silicon. Mater. Sci. Semicond. Process. 2019, 93, 295-298. [CrossRef]

67. Jiang, Y.; Zhao, C.; Liu, S.; Huang, Q. Polysilicon-Al Based Ohmic Contact on p-Type 3C-SiC Film Grown on Silicon Substrate. In Proceedings of the 2006 8th Internation Conference on Solid-State and Integrated Circuit Technology Proceedings, Shanghai, China, 23-26 October 2006; pp. 938-940.

68. Schöner, A.; Krieger, M.; Pensl, G.; Abe, M.; Nagasawa, H. Fabrication and Characterization of 3C-SiC-Based MOSFETs. Chem. Vap. Depos. 2006, 12, 523-530. [CrossRef]

69. Afanas'ev, V.V.; Ciobanu, F.; Pensl, G.; Stesmans, A. Contributions to the Density of Interface States in SiC MOS Structures. In Silicon Carbide: Recent Major Advances; Choyke, W.J., Matsunami, H., Pensl, G., Eds.; Springer: Berlin/Heidelberg, Germany, 2004; pp. 343-371. [CrossRef]

70. Afanasev, V.; Bassler, M.; Pensl, G.; Shulz, M. Intrinsic SiC $/ \mathrm{SiO}_{2}$ Interface States. Phys. Stat. Sol. 1997, 162, 321-337. [CrossRef]

71. Esteve, R. Fabrication and Characterization of 3C- and $4 \mathrm{H}-\mathrm{SiC}$ MOSFETs. Doctoral Thesis, KTH, School of Information and Communication Technology (ICT), Integrated Devices and Circuits, Stockholm, Sweden, 2011.

72. Esteve, R.; Schöner, A.; Reshanov, S.A.; Zetterling, C.-M.; Nagasawa, H. Comparative Study of Thermally Grown Oxides on N-Type Free Standing 3C-SiC (001). J. Appl. Phys. 2009, 106, 44513. [CrossRef]

73. Wan, J.; Capano, M.A.; Melloch, M.R.; Cooper, J.A. N-Channel 3C-SiC MOSFETs on Silicon Substrate. IEEE Electron Device Lett. 2002, 23, 482-484. [CrossRef]

74. Abe, M.; Nagasawa, H.; Ericsson, P.; Strömberg, H.; Bakowski, M.; Schöner, A. High Current Capability of 3C-SiC Vertical DMOSFETs. Microelectron. Eng. 2006, 83, 24-26. [CrossRef]

75. Krieger, M.; Beljakowa, S.; Trapaidze, L.; Frank, T.; Weber, H.B.; Pensl, G.; Hatta, N.; Abe, M.; Nagasawa, H.; Schöner, A. Analysis of Interface Trap Parameters from Double-Peak Conductance Spectra Taken on N-Implanted 3C-SiC MOS Capacitors. Phys. Status Solidi Basic Res. 2008, 245, 1390-1395. [CrossRef]

76. Li, F.; Vavasour, O.J.; Walker, M.; Martin, D.M.; Sharma, Y.K.; Russell, S.A.O.; Jennings, M.R.; Pérez-Tomás, A.; Mawby, P.A. Physical Characterisation of 3C-SiC(001)/ $/ \mathrm{SiO}_{2}$ Interface Using XPS. Mater. Sci. Forum 2017, 897, 151-154. [CrossRef]

77. Arora, R.; Rozen, J.; Fleetwood, D.M.; Galloway, K.F.; Zhang, C.X.; Han, J.; Dimitrijev, S.; Kong, F.; Feldman, L.C.; Pantelides, S.T.; et al. Charge Trapping Properties of 3C- and 4H-SiC MOS Capacitors With Nitrided Gate Oxides. IEEE Trans. Nucl. Sci. 2009, 56, 3185-3191. [CrossRef]

78. Matocha, K.; Beaupre, R. Time-Dependent Dielectric Breakdown of Thermal Oxides on 4H-SiC. Mater. Sci. Forum 2007, 556, 675-678. [CrossRef]

79. Fiorenza, P.; Schilirò, E.; Giannazzo, F.; Bongiorno, C.; Zielinski, M.; La Via, F.; Roccaforte, F. On the Origin of the Premature Breakdown of Thermal Oxide on 3C-SiC Probed by Electrical Scanning Probe Microscopy. Appl. Surf. Sci. 2020, 526, 146656. [CrossRef] 
80. Esteve, R.; Schöner, A.; Reshanov, S.A.; Zetterling, C.-M.; Nagasawa, H. Advanced Oxidation Process Combining Oxide Deposition and Short Postoxidation Step for N-Type 3C- and 4H-SiC. J. Appl. Phys. 2009, 106, 44514. [CrossRef]

81. Anzalone, R.; Privitera, S.; Camarda, M.; Alberti, A.; Mannino, G.; Fiorenza, P.; Di Franco, S.; La Via, F. Interface State Density Evaluation of High Quality Hetero-Epitaxial 3C-SiC(001) for High-Power MOSFET Applications. Mater. Sci. Eng. B 2015, 198, 14-19. [CrossRef]

82. Sharma, Y.K.; Li, F.; Jennings, M.R.; Fisher, C.A.; Pérez-Tomás, A.; Thomas, S.; Hamilton, D.P.; Russell, S.A.O.; Mawby, P.A. High-Temperature (1200-1400 $\left.{ }^{\circ} \mathrm{C}\right)$ Dry Oxidation of 3C-SiC on Silicon. J. Electron. Mater. 2015, 44, 4167-4174. [CrossRef]

83. Furukawa, K.; Uemoto, A.; Shigeta, M.; Suzuki, A.; Nakajima, S. 3C-SiC P-n Junction Diodes. Appl. Phys. Lett. 1986, $48,1536-1537$. [CrossRef]

84. Davis, R.F.; Kelner, G.; Shur, M.; Palmour, J.W.; Edmond, J.A. Thin Film Deposition and Microelectronic and Optoelectronic Device Fabrication and Characterization in Monocrystalline Alpha and Beta Silicon Carbide. Proc. IEEE 1991, 79, 677-701. [CrossRef]

85. Neudeck, P.G.; Larkin, D.J.; Starr, J.E.; Powell, J.A.; Salupo, C.S.; Matus, L.G. Greatly Improved 3C-SiC p-n Junction Diodes Grown by Chemical Vapor Deposition. IEEE Electron Device Lett. 1993, 14, 136-139. [CrossRef]

86. Shenoy, P.; Moki, A.; Baliga, B.J.; Alok, D.; Wongchotigul, K.; Spencer, M. Vertical Schottky Barrier Diodes on 3C-SiC Grown on Si. In Proceedings of the 1994 IEEE International Electron Devices Meeting, San Francisco, CA, USA, 11-14 December 1994; pp. 411-414. [CrossRef]

87. Cherkaoui, K.; Duane, R.; Ward, P.; Blake, A. Fabrication and Characterisation of Silicide/3C-SiC/Si Contacts for Schottky Barrier Diode Application. ECS Meet. Abstr. 2020, 23, 1334. [CrossRef]

88. Arvanitopoulos, A.; Li, F.; Jennings, M.R.; Perkins, S.; Gyftakis, K.N.; Antoniou, M.; Mawby, P.; Lophitis, N. Experimental Investigation and Verification of Traps Affecting the Performance of 3C-SiC-on-Si Schottky Barrier Diodes. In Proceedings of the 2019 IEEE Energy Conversion Congress and Exposition (ECCE), Baltimore, MD, USA, 29 September-3 October 2019; pp. 1941-1947. [CrossRef]

89. Wang, L.; Dimitrijev, S.; Han, J.; Tanner, P.; Iacopi, A.; Hold, L. Demonstration of P-Type 3C-SiC Grown on 150 mm Si(100) Substrates by Atomic-Layer Epitaxy at $1000{ }^{\circ}$ C. J. Cryst. Growth 2011, 329, 67-70. [CrossRef]

90. Shibahara, K.; Takeuchi, T.; Matsunami, H.; Nishino, S. Electrical Properties of Undoped and Ion-Implanted Cubic SiC Grown on Si(100) by Chemical Vapor Deposition. Jpn. J. Appl. Phys. 1989, 28, 1341-1347. [CrossRef]

91. Tyagi, R.; Chow, T.P. Self-Enclosed vs. LOPOS-Terminated Lateral Planar p/Sup +/n and n/Sup +/p Junctions in 3C-SiC/Si. In Proceedings of the 8th International Symposium on Power Semiconductor Devices and Ics, ISPSD '96 Proceedings, Lahaina, HI, USA, 20-23 May 1996; pp. 115-118. [CrossRef]

92. Hatta, N.; Kawahara, T.; Yagi, K.; Nagasawa, H.; Reshanov, S.A.; Schöner, A. Reliable Method for Eliminating Stacking Fault on 3C-SiC(001). Mater. Sci. Forum 2012, 717, 173-176. [CrossRef]

93. Fisicaro, G.; Bongiorno, C.; Deretzis, I.; Giannazzo, F.; La Via, F.; Roccaforte, F.; Zielinski, M.; Zimbone, M.; La Magna, A. Genesis and Evolution of Extended Defects: The Role of Evolving Interface Instabilities in Cubic SiC. Appl. Phys. Rev. 2020, 7, 21402. [CrossRef]

94. Singh, R.; Cooper, J.A.; Melloch, M.R.; Chow, T.P.; Palmour, J.W. SiC Power Schottky and PiN Diodes. IEEE Trans. Electron Devices 2002, 49, 665-672. [CrossRef]

95. Bu, Y.; Yoshimoto, H.; Watanabe, N.; Shima, A. Fabrication of 4H-SiC PiN Diodes without Bipolar Degradation by Improved Device Processes. J. Appl. Phys. 2017, 122, 244504. [CrossRef]

96. Fisher, C.A.; Jennings, M.R.; Sharma, Y.K.; Hamilton, D.P.; Gammon, P.M.; Pérez-Tomás, A.; Thomas, S.M.; Burrows, S.E.; Mawby, P.A. Improved Performance of $4 \mathrm{H}-\mathrm{SiC}$ PiN Diodes Using a Novel Combined High Temperature Oxidation and Annealing Process. IEEE Trans. Semicond. Manuf. 2014, 27, 443-451. [CrossRef]

97. Bakowski, M.; Schöner, A.; Ericsson, P.; Stromberg, H.; Nagasawa, H.; Abe, M. Development of 3C-SiC MOSFETs. J. Telecommun. Inf. Tech. 2007, 2, 49-56.

98. Japanese Push SiC Power. III-Vs Rev. 2004, 17, 35.

99. Nagasawa, H.; Yagi, K.; Kawahara, T.; Hatta, N.; Abe, M.; Schöner, A.; Bakowski, M.; Ericsson, P.; Pensl, G. Challenges for Improving the Crystal Quality of 3C-SiC Verified with MOSFET Performance. Mater. Sci. Forum 2009, 600, 89-94. [CrossRef]

100. Nagasawa, H.; Yagi, K.; Kawahara, T.; Hatta, N.; Abe, M. Hetero- and Homo-Epitaxial Growth of 3C-SiC for MOS-FETs. Microelectron. Eng. 2006, 83, 185-188. [CrossRef]

101. Kobayashi, M.; Uchida, H.; Minami, A.; Sakata, T.; Esteve, R.; Schöner, A. 3C-SiC MOSFET with High Channel Mobility and CVD Gate Oxide. Mater. Sci. Forum 2011, 679, 645-648. [CrossRef]

102. Schoner, A.; Bakowski, M.; Ericsson, P.; Stromberg, H.; Nagasawa, H.; Abe, M. Vertical MOSFET Devices Fabricated on 3C-SiC with High and Low Material Quality. MRS Online Proc. Libr. 2011, 911, 1303. [CrossRef]

103. Lee, K.K.; Ishida, Y.; Ohshima, T.; Kojima, K.; Tanaka, Y.; Takahashi, T.; Okumura, H.; Arai, K.; Kamiya, T. N-Channel MOSFETs Fabricated on Homoepitaxy-Grown 3C-SiC Films. IEEE Electron Device Lett. 2003, 24, 466-468. [CrossRef]

104. Uchida, H.; Minami, A.; Sakata, T.; Nagasawa, H.; Kobayashi, M. High Temperature Performance of 3C-SiC MOSFETs with High Channel Mobility. Mater. Sci. Forum 2012, 717, 1109-1112. [CrossRef] 